\title{
The Effects of Vitamin D Supplementation During Infancy on Growth During the First 2 Years of Life
}

\section{Hauta-Alus, Helena $\mathrm{H}$.}

2021-03

Hauta-Alus , H H , Holmlund-Suila , E M , Kajantie , E, Rosendahl , J , Valkama , S M , Enlund-Cerullo, M , Andersson, S \& Mäkitie , O 2021, ' The Effects of Vitamin D Supplementation During Infancy on Growth During the First 2 Years of Life ' , Journal of Clinical Endocrinology and Metabolism , vol. 106 , no. 3 , pp. E1140-E1155 . https://doi.org/10.1210/clinem/dgaa943

http://hdl.handle.net/10138/337884

https://doi.org/10.1210/clinem/dgaa943

unspecified

acceptedVersion

Downloaded from Helda, University of Helsinki institutional repository.

This is an electronic reprint of the original article.

This reprint may differ from the original in pagination and typographic detail.

Please cite the original version. 


\section{The Effects of Vitamin D Supplementation During Infancy on Growth During}

\section{2 the First Two Years of Life}

3 Helena H. Hauta-alus ${ }^{1,2,3}$, Elisa M. Holmlund-Suila ${ }^{1,2}$, Eero Kajantie ${ }^{1,3,4,5}$, Jenni Rosendahl ${ }^{1,2}$, Saara M.

4 Valkama $^{1,2}$, Maria Enlund-Cerullo ${ }^{1,2}$, Sture Andersson ${ }^{1}$, Outi Mäkitie ${ }^{1,6,7}$

$6 \quad{ }^{1}$ Children's Hospital, Pediatric Research Center, University of Helsinki and Helsinki University

7 Hospital, Helsinki, Finland

$8 \quad{ }^{2}$ Research Program for Clinical and Molecular Metabolism, Faculty of Medicine, University of

9 Helsinki, Helsinki, Finland

$10 \quad{ }^{3}$ Finnish Institute for Health and Welfare (THL), Helsinki, Finland

$11{ }^{4}$ PEDEGO Research Unit, MRC Oulu, Oulu University Hospital and University of Oulu, Oulu,

12 Finland

$13{ }^{5}$ Department of Clinical and Molecular Medicine, Norwegian University of Science and Technology,

14 Trondheim, Norway

$15{ }^{6}$ Department of Molecular Medicine and Surgery, Karolinska Institutet, and Clinical Genetics,

16 Karolinska University Laboratory, Karolinska University Hospital, Stockholm, Sweden

$17 \quad{ }^{7}$ Folkhälsan Institute of Genetics, Helsinki, Finland

18 Short title: Vitamin D and early childhood growth

19 Keywords: vitamin D supplementation, 25-hydroxyvitamin D, maternal, infant, early childhood

20 growth, clinical trial

21 Corresponding author and person whom reprint requests should be addressed:

22 Helena Henrietta Hauta-alus, Children's Hospital, University of Helsinki and Helsinki University

23 Hospital, Helsinki, Biomedicum 2 C, P.O. Box 705, 00020 HUS, Finland. Tel +358 947175731. 
25 Grants supporting the writing of the paper: Päivikki and Sakari Sohlberg Foundation, Juho Vainio

26 Foundation, European Commission (Horizon 2020), Academy of Finland, Foundation for Pediatric

27 Research, Signe and Ane Gyllenberg Foundation, Sigrid Juselius Foundation, Novo Nordisk

28 Foundation, Foundation for Cardiovascular Research, Diabetes Research Foundation, Finska

29 Läkaresällskapet, A Special Governmental Subsidy for Clinical Research, Folkhälsan Research

30 Foundation, Pediatric Research Center and Orion Research Foundation.

31 Disclosure summary: The authors have nothing to disclose.

32 The project protocol is registered at ClinicalTrials.gov: NCT01723852. 
Abstract

Context. The relationship between maternal and infant vitamin D and early childhood growth remains inadequately understood.

Objective. To investigate how maternal and child 25-hydroxyvitamin D [25(OH)D] and vitamin D supplementation impact growth during the first 2 years of life.

Design. A randomized, double-blinded intervention study.

Setting. A single-center study from pregnancy until offspring age 2 years.

Participants. Altogether 812 term-born children with complete data, recruited at Maternity Hospital.

Intervention. Children received daily vitamin $\mathrm{D}_{3}$ supplementation $10 \mu \mathrm{g}$ (Group-10) or $30 \mu \mathrm{g}$ (Group30) from age 2 weeks to 2 years.

Main outcome measures. Anthropometry and growth rate at age 1 and 2 years.

Results. Toddlers born to mothers with Pregnancy $25(\mathrm{OH}) \mathrm{D}>125 \mathrm{nmol} / \mathrm{L}$ were at 2 years lighter and thinner than the reference group with 25(OH)D 50-74.9 nmol/L $(\mathrm{P}<0.010)$. Mean 2-year 25(OH)D concentrations were $87 \mathrm{nmol} / \mathrm{L}$ in Group-10 and $118 \mathrm{nmol} / \mathrm{L}$ in Group-30 (P<0.001). When Group-30 was compared with Group-10, difference in body size was not statistically significant $(\mathrm{P}>0.053)$, but Group-30 had slower growth in length and head circumference between 6 months and 1 year $(\mathrm{P}<0.047)$, and more rapid growth in weight and length-adjusted weight between 1 and 2 years $(\mathrm{P}<0.043)$. Toddlers in the highest quartile of $25(\mathrm{OH}) \mathrm{D}(>121 \mathrm{nmol} / \mathrm{L})$ were shorter (mean difference 0.2 SD score (SDS), $\mathrm{P}=0.021$ ), lighter (mean difference 0.4 SDS, $\mathrm{P}=0.001$ ) and thinner (in lengthadjusted weight) (mean difference 0.4 SDS, $\mathrm{P}=0.003)$ compared with the lowest quartile $(<81.2$ $\mathrm{nmol} / \mathrm{L})$.

Conclusion. Vitamin D and early childhood growth may have an inverse U-shaped relationship. 
59 Vitamin D has a vital role in childhood growth and development and chronic and severe vitamin D

60 deficiency leads to rickets, stunted growth and delayed neuromuscular development (1). Maternal

61 vitamin D deficiency may increase the likelihood of pregnancy complications and prenatal growth

62 restriction (2-4). Vitamin D status is defined by blood 25-hydroxyvitamin D concentration

$63[25(\mathrm{OH}) \mathrm{D}]$, which is generally considered sufficient at values at or above $50 \mathrm{nmol} / / \mathrm{L}(1,5,6)$. Vitamin

64 D insufficiency $(25(\mathrm{OH}) \mathrm{D}$ below $50 \mathrm{nmol} / \mathrm{L})$ is common worldwide $(7,8)$, the prevalence ranging from $7 \%$ in Northern Europe to $90 \%$ in the Middle East (5). Especially populations with inadequate sunlight exposure are at an increased risk. In addition to endogenously produced vitamin $\mathrm{D}$ in the skin, diet and supplements are important sources of vitamin D.

A global consensus recommendation for prevention of vitamin D deficiency rickets was published in 2016 (1). The recommended vitamin D supplementation was a daily dose of $15 \mu \mathrm{g}$ for pregnant women and $10 \mu \mathrm{g}$ for infants (1). The latest guidelines given by the Finnish national health authorities in 2018 recommend a daily total intake of $10 \mu \mathrm{g}$ for pregnant women and infants (9). WHO does not recommend vitamin D supplementation for pregnant women (10). Some researchers consider the target $25(\mathrm{OH}) \mathrm{D}$ level to be much higher than $50 \mathrm{nmol} / \mathrm{L}$, preferably $>75-100 \mathrm{nmol} / \mathrm{L}$, and therefore recommend higher supplemental vitamin D intake, up to $100 \mu \mathrm{g} / \mathrm{d}$, also for pregnant women (11-13).

In general, it is presumed that vitamin D enhances childhood growth, although evidence is limited and conflicting, and in particular the linearity of the relationship is not known $(3,14-17)$. The association between $25(\mathrm{OH}) \mathrm{D}$ concentrations and growth might be non-linear and hence dissimilar at different ranges of $25(\mathrm{OH}) \mathrm{D}$, which could explain discrepancies between studies.

The effect of vitamin D on childhood growth pattern may best be seen during the prenatal period and infancy due to rapid growth rate. Early growth is particularly relevant for later health outcomes as specific growth patterns have been associated with increased risk of chronic diseases, for example through body composition and metabolic changes. While the associations between prenatal growth 
and adult disease are particularly well established (18), growth during the first years after birth is also important $(19,20)$.

Vitamin D intervention in Infants (VIDI) -study is a double-blinded and randomized clinical trial (RCT) comparing the effect of daily vitamin D supplementation of $10 \mu \mathrm{g}$ or $30 \mu \mathrm{g}$ from birth until 2 years of age, the primary outcomes being bone strength and infection episodes $(21,22)$. We previously reported an unexpected association between higher maternal and infant $25(\mathrm{OH}) \mathrm{D}$ with slower infant growth in the VIDI cohort; mothers with $25(\mathrm{OH}) \mathrm{D}$ above $125 \mathrm{nmol} / \mathrm{L}$ had the smallest infants at 6 months and 1 year of age (23). In the current study, we aimed to investigate if maternal and child $25(\mathrm{OH}) \mathrm{D}$ further predict growth parameters at 2 years of age, and whether the dose of vitamin $\mathrm{D}$ supplementation in infancy influences childhood growth pattern from 6 months to 2 years of age.

Materials and Methods

95

\section{Subjects}

In Helsinki, Finland (60 ${ }^{\text {th }}$ parallel North), we recruited at Kätilöopisto Maternity Hospital 987 families to the VIDI study between January 2013 and June 2014. A description of the recruitment and study protocol has been published previously $(21,22)$. Briefly, according to the inclusion criteria, the mothers were of Northern European origin without regular medication and with singleton pregnancy. Exclusion criteria for the newborns were: nasal continuous positive airway pressure treatment or need for nasogastric tube > one day, intravenous glucose infusion, seizures, and duration of phototherapy > three days. The infants were born between 37 and 42 weeks of gestation with birth weights appropriate for gestational age (standard deviation score [SDS] between -2.0 and +2.0 ).

Infants were randomized to receive daily vitamin $\mathrm{D}_{3}$ supplementation with either $10 \mu \mathrm{g}$ [hereafter referred to as Group-10] or $30 \mu \mathrm{g}$ [hereafter referred to as Group-30] from age 2 weeks to 2 years. The study included three study visits at the age of 6 months, 1 and 2 years, and retrospectively and prospectively collected questionnaires. 
Written informed consent was obtained from the parents at recruitment. This study was conducted

109 according to the guidelines laid down in the Declaration of Helsinki. Ethical approval was obtained

110 from the Research Ethics Committee of the Hospital District of Helsinki and Uusimaa

111 (107/13/03/03/2012). The project protocol is registered at ClinicalTrials.gov (NCT01723852).

112 Of the recruited 987 families, we excluded 12 who did not meet the inclusion criteria and 1 infant

113 diagnosed with Rieger syndrome, leaving 974 study participants. Further, 126 children were excluded

114 from the present analysis due to lacking data on length and additional 9 due to lacking data on

$11525(\mathrm{OH}) \mathrm{D}$ at 2 years' follow-up. This resulted in a final number of 812 study subjects. Number of

116 subjects varies in some analyses and are presented in tables and figures.

117 Family data

118 Parental data were obtained from a self-administered baseline questionnaire, filled out after delivery,

119 and from medical records. Parental heights $(\mathrm{cm})$ and weights $(\mathrm{kg})$ before pregnancy were standardized into sex-specific z-scores. Body mass index (BMI) was calculated $\left(\mathrm{kg} / \mathrm{m}^{2}\right)$.

Parental education level was categorized into 'lower' and 'higher' education (lower =lower or upper secondary or post-secondary non-tertiary education/less than a bachelor degree, higher $=$ first or second stage of tertiary education/at least a bachelor degree), according to the highest received degree of either parent. Parental smoking status was assessed before pregnancy and at infant age of 2 years and applied as a merged previous and current smoking status. Family income level was enquired with a questionnaire completed at infant age of 2 years.

\section{Child anthropometrics}

Birth size was measured by midwives according to standard procedures. The measurements were collected from birth records, and transformed to parity-, gestational age- and sex-specific standard deviation scores (SDS) based on national newborn body size curves (24). Infant weight (kg), length $(\mathrm{cm})$ and head circumference $(\mathrm{cm})$ were measured at 6 months and at 1 and 2 years' follow-up visits by a pediatrician or a research nurse. At 1 and 2 years, mid-upper-arm circumference (MUAC) (mm) was measured. Length was measured with a tabletop meter in a supine position, and weight with an 
electronic scale (Seca ${ }^{\circledR}$, Hamburg, Germany). Weight, length, length-adjusted weight and head circumference were expressed as SDS using age- and sex-specific national references (25) and considered normal when between -2.0 and +2.0 SDS. BMI at 2 years of age was calculated and together with MUAC, standardized into sex-specific z-score within the present study population.

Study compliance and duration of breastfeeding were determined based on prospectively collected study diaries. Average vitamin D intake from food at 1 year of age was calculated based on 3-day food records (26).

\section{Biochemical analyses}

We analyzed 25(OH)D concertation from maternal serum samples in early pregnancy, at birth from umbilical cord blood (UCB), and from infant serum samples at the age of 1 and 2 years using the IDSiSYS fully automated immunoassay system with chemiluminescence detection (Immunodiagnostic Systems Ltd., Bolton, UK). Pregnancy samples were collected at prenatal clinics on average at gestational week 11 between June 2012 and February 2014 as part of the mothers' normal follow-up [hereafter referred to as Pregnancy 25(OH)D] (23). UCB for 25(OH)D measurement was obtained at birth (gestational weeks 37 to 42) between January 2013 and June 2014 [hereafter referred to as UCB 25(OH)D]. Maternal 25(OH)D refers to both Pregnancy and UCB 25(OH)D. Children's samples at 1 year follow-up were obtained between December 2013 and May 2015 [hereafter referred to as Infant 25(OH)D], and samples at 2 years follow-up between December 2014 and May 2016 [hereafter referred to as Toddler $25(\mathrm{OH}) \mathrm{D}]$.

Pregnancy serum and UCB plasma 25(OH)D were analyzed simultaneously and Infant and Toddler serum $25(\mathrm{OH}) \mathrm{D}$ in a separate series with intra-assay variation $<7 \%$ for Pregnancy $25(\mathrm{OH}) \mathrm{D}$ and Infant/Toddler $25(\mathrm{OH}) \mathrm{D}$, and $<13 \%$ for UCB $25(\mathrm{OH}) \mathrm{D}$. The quality and accuracy of the $25(\mathrm{OH}) \mathrm{D}$ analyses are validated on an ongoing basis by participation in the vitamin D External Quality Assessment Scheme (DEQAS, Charing Cross Hospital, London, UK). The method showed a $\leq 8 \%$ positive bias against NIST Reference Measurement Procedure. Detailed information on the 25(OH)D analysis has been previously reported (22). 
160 Vitamin $\mathrm{D}$ sufficiency was defined as $25(\mathrm{OH}) \mathrm{D} \geq 50 \mathrm{nmol} / \mathrm{L}(5,6)$. Further, we used additional cut-off 161 values for $25(\mathrm{OH}) \mathrm{D}$, namely $75 \mathrm{nmol} / \mathrm{L}$, which has been suggested to be a higher threshold value for 162 bone health (11), and $125 \mathrm{nmol} / \mathrm{L}$, above which values have been related to health risks $(5,6)$.

163

164 Statistical analyses

165

166

167

The normality of the variables was visually inspected, and statistical tests were chosen accordingly. Infant and family characteristics were reported as means, standard deviations, and percentages. Covariates were chosen based on literature and consistent association with several growth measures. Missing values of covariates were multiple imputed (5 imputations). The difference between intervention groups was examined with Independent-Samples T-test, Mann-Whitney U-test or Pearson Chi-Square test.

Growth rate, referred to here as conditional growth, was investigated by using the residuals from linear regression models in which body size SDS at each successive age was regressed on corresponding body size SDS at all earlier ages (27). These residuals indicate how much a measurement of body size at each time point differs from that predicted by the corresponding measurements at earlier time points.

We used univariate and multivariate linear and quadratic regression analysis to determine associations between $25(\mathrm{OH}) \mathrm{D}$ and growth measures. We show in the tables unadjusted model 1, and model 2 adjusted with corresponding birth size, maternal and paternal height z-scores and intervention group. All analyses were also stratified by intervention group and shown in relevant tables separately. Additional adjustments were conducted with covariates of maternal prepregnancy BMI and paternal BMI, parental smoking status, parental education level, family income level, and duration of breastfeeding. These results are reported in the text only if an effect was observed.

Further, we investigated child growth in categories of 25(OH)D with ANCOVA adjusted for corresponding birth size SDS, maternal and paternal height z-scores and intervention group. Maternal $25(\mathrm{OH}) \mathrm{D}$ concentrations were categorized into four groups; $<50 \mathrm{nmol} / \mathrm{L}, 50-74.9 \mathrm{nmol} / \mathrm{L}$ (reference 
group), $75-125 \mathrm{nmol} / \mathrm{L}$ and $>125 \mathrm{nmol} / \mathrm{L}$, and Toddler 25(OH)D into three groups; $<75 \mathrm{nmol} / \mathrm{L}$ (reference group), $75-125 \mathrm{nmol} / \mathrm{L}$ and $>125 \mathrm{nmol} / \mathrm{L}$ due to only five toddlers having a concentration below $50 \mathrm{nmol} / \mathrm{L}$. In addition, Toddler $25(\mathrm{OH}) \mathrm{D}$ concentration was categorized into quartiles; $<81.2$ $\mathrm{nmol} / \mathrm{L}$ (reference group), 81.2-99.2 $\mathrm{nmol} / \mathrm{L}, 99.3-120.7 \mathrm{nmol} / \mathrm{L}$ and $>121 \mathrm{nmol} / \mathrm{L}$. Differences in child size between categories were compared with linear regression applying 50-74.9 nmol/L, <75 $\mathrm{nmol} / \mathrm{L}$ or first quartile as a reference group. Additional adjustments were conducted with covariates of maternal prepregnancy BMI and paternal BMI, parental smoking status, parental education level, family income level, and duration of breastfeeding. These results are reported in the text only if an effect on the results was observed.

Statistical significance was determined at $\mathrm{P}<0.05$. All statistical analyses were conducted using the IBM SPSS program for Windows, version 25 (IBM, Chicago, IL, USA).

\section{Results}

Subject characteristics are shown in Tables 1 and 2 according to intervention groups. Infant 25(OH)D concentrations were higher at the age of 1 and 2 years in Group-30 compared with Group-10 but no difference was observed in mean values of body size parameters (22). However, when we compared mean conditional growth values indicating growth rate, we discovered that growth in length and head circumference were slower between 6 months and 1 year, but growth in weight and length-adjusted weight were accelerated between 1 and 2 years in Group-30 compared with Group-10 (Figures 1 and 2). Almost all subjects ( $>92 \%$ ) had normal body size (measured values between -2.0 and +2.0 SDS) at all time points.

At 1 year, total $(r=0.56, p<0.001)$ and supplemental vitamin $D$ intake $(r=0.59, p<0.001)$ correlated with Infant 25(OH)D. Similarly, supplemental vitamin D intake at 2 years correlated with Toddler 25(OH)D $(\mathrm{r}=0.61, \mathrm{p}<0.001)$. To exclude the possibility that body size as such, by possible dilution or fat mass, affected how vitamin D intake was reflected in $25(\mathrm{OH}) \mathrm{D}$ concentration, we tested 
211 interactions between supplemental vitamin D intake (compliance-based $\mu \mathrm{g} / \mathrm{day}$ ) and weight $(\mathrm{kg})$ in all

212 linear models, and no interaction was detected.

213 No linear relation existed between Maternal 25(OH)D and offspring body size at 2 years (Table 3).

214 But the mothers whose Pregnancy 25(OH)D was above $125 \mathrm{nmol} / \mathrm{L}$ had lighter (measured in weight)

215 and thinner (measured in length-adjusted weight, MUAC and BMI) children at 2 years of age

216 compared with the reference group of children with Pregnancy 25(OH)D 50-74.9 nmol/L (Figure 3).

217 A quadratic association was confirmed between Pregnancy 25(OH)D and the children's length-

218 adjusted weight and BMI at 2 years $(\mathrm{p}<0.003)$ suggesting an inverse $\mathrm{U}$-shaped association (Figure 3 ).

219 Toddlers at 2 years of age with UCB $25(\mathrm{OH}) \mathrm{D}$ below $50 \mathrm{nmol} / \mathrm{L}$ at birth were taller than the reference

220 group of 50-74.9 $\mathrm{nmol} / \mathrm{L}$ (Figure 4) but this association was attenuated after adjustment for maternal

221 prepregnancy BMI, paternal BMI, parental smoking status, parental education level, family income

222 level, and duration of breastfeeding ( $\mathrm{p}=0.062$ ). Toddlers with UCB 25(OH)D above $125 \mathrm{nmol} / \mathrm{L}$ were

223 thinner (in BMI) at 2 years compared with the reference group of 50-74.9 nmol/L (Figure 4). Higher

224 Pregnancy 25(OH)D and UCB 25(OH)D associated with accelerated growth in head circumference at

2252 years, while no association for other growth parameters was observed (Table 4).

226 We have previously reported that across the VIDI cohort, higher Infant 25(OH)D at 1 year associated

227 with slower growth at 1 year in several growth parameters (23). In the present study, we stratified the

228 results according to intervention group, and observed that linear associations between Infant 25(OH)D

229 and growth measures disappeared in Group-10 but were enhanced in Group-30 (Table 5).

230 At 2 years in the whole cohort, higher Toddler $25(\mathrm{OH}) \mathrm{D}$ associated linearly with smaller body size in

231 all other parameters except head circumference (Table 6). The association between Toddler 25(OH)D

232 and length attenuated after full adjustment for maternal and paternal factors $(\mathrm{p}=0.054)$. After

233 stratification these linear results at 2 years of age by intervention group, associations between Toddler

$23425(\mathrm{OH}) \mathrm{D}$ and growth measures attenuated for length and remained for weight, length-adjusted weight

235 and BMI in both groups, while for MUAC the association disappeared in Group-10 and remained in

236 Group-30 (Table 6). 
237 In the whole cohort, a quadratic association was observed between Toddler 25(OH)D and head

238 circumference $(\mathrm{p}<0.035)$ implying an inverse U-shaped association (Figure 5). Toddler 25(OH)D had

239 no linear relation for conditional growth at 2 years (Table 4).

240 When comparing growth parameters in three groups of Toddler $25(\mathrm{OH}) \mathrm{D}$, those with $25(\mathrm{OH}) \mathrm{D}$ above

$241125 \mathrm{nmol} / \mathrm{L}$ (highest group) were lighter (in weight) and thinner (in length-adjusted weight and BMI)

242 compared with the reference group with 25(OH)D $<75 \mathrm{nmol} / \mathrm{L}$ (Figure 5). Toddlers with 25(OH)D

243 between $75 \mathrm{nmol} / \mathrm{L}$ and $125 \mathrm{nmol} / \mathrm{L}$ had larger head circumference than the reference group of $<75$

$244 \mathrm{nmol} / \mathrm{L}$ (Figure 5). Figure 6 shows adjusted mean values for growth measures in quartiles of Toddler

$24525(\mathrm{OH}) \mathrm{D}$. Children in the highest quartile of 25(OH)D (>121 nmol/L) were shorter (in length), lighter

246 (in weight) and thinner (in length-adjusted weight and BMI) than the reference group in the lowest

247 quartile $(<81.2 \mathrm{nmol} / \mathrm{L})$ (Figure 6).

248 


\section{Discussion}

250 We examined the association of vitamin D in pregnancy and in early childhood with child growth in an RCT-based cohort in Northern Europe with low sunlight exposure. VIDI study is an intervention trial with $>800$ infants comparing the effect of vitamin D supplementation of $10 \mu \mathrm{g} / \mathrm{d}$ and $30 \mu \mathrm{g} / \mathrm{d}$ during the first 2 years of life.

The dose of vitamin D supplementation had little effect on early childhood growth, as the mean body size measures were similar in both intervention groups (22). However, growth in length and head circumference was slower between 6 months and 1 year but growth in weight and length-adjusted weight was more rapid between 1 and 2 years in Group-30 compared with Group-10. Almost all children were vitamin D sufficient ( $\geq 50 \mathrm{nmol} / \mathrm{L})$ and $21 \%$ of the children had $25(\mathrm{OH}) \mathrm{D}$ above 125 $\mathrm{nmol} / \mathrm{L}$ at 2 years. The possible effect of vitamin D on growth may be mediated through $25(\mathrm{OH}) \mathrm{D}$ concentration, as we observed that higher $25(\mathrm{OH}) \mathrm{D}$ in early pregnancy, at birth, and at 1 and 2 years of age associated with smaller body size in the offspring during 2 years' follow-up.

Previous studies on vitamin D and growth in early childhood have been inconclusive $(15,16,28-30)$. We have previously reported an inverse association between both Maternal 25(OH)D and Infant $25(\mathrm{OH}) \mathrm{D}$ and growth measures at age 6 months and 1 year (23). These findings were obtained before the intervention code was opened and were based solely on measured $25(\mathrm{OH}) \mathrm{D}$ concentration. In line with a Danish study (28) and contrary to an Equadorian study (30), we now observed that higher Toddler 25(OH)D at age 2 years associated with smaller anthropometric growth parameters. However, at 1 year, the associations were not observed within Group-10 but were enhanced in Group30. This is consistent with a non-linear relationship, implying that the effect of vitamin D dosage on growth would depend on the attained 25(OH)D. At 2 years, these inverse associations between $25(\mathrm{OH}) \mathrm{D}$ and most growth measures remained in both intervention groups. This might be explained by differing growth rates between intervention groups and time points. The intervention effect may be smaller at 2 years than at 1 year because other factors such as food intake, physical activity and 
endocrine factors, especially growth hormone secretion, have a larger role in child growth after infancy.

276 We also applied both clinical cut-off values and quartiles for Toddler 25(OH)D at 2 years. These 277 results demonstrated that toddlers with $25(\mathrm{OH}) \mathrm{D}$ above $125 \mathrm{nmol} / \mathrm{L}$ or $121 \mathrm{nmol} / \mathrm{L}$ were the shortest 278 (in length), lightest (in weight) and thinnest (in length-adjusted weight and BMI) at 2 years of age. In addition to our previous findings $(31,32)$, others have found unfavorable and non-linear relations between vitamin $\mathrm{D}$ and child health outcomes $(33,34)$.

In longitudinal analysis, maternal $25(\mathrm{OH}) \mathrm{D}$ concentration in early pregnancy and at birth had no linear relation to offspring growth anthropometry at 2 years. However, mothers with $25(\mathrm{OH}) \mathrm{D}$ above $125 \mathrm{nmol} / \mathrm{L}$ in early pregnancy, had the lightest and thinnest children at age 2 years, suggesting that maternal 25(OH)D may affect infant growth until age 1 year but the effect diminishes thereafter, possibly due to catch-up growth $(23,35,36)$. Furthermore, other factors at an older age possibly have a larger role than maternal $25(\mathrm{OH}) \mathrm{D}$ if it is in the "moderate range". In line with our findings,

Christensen et al. found an inverse relation between UCB 25(OH)D and offspring leg length from age 1.5 to 3 years of age (37). Further, U- or J-shaped association have been suggested to exist between maternal 25(OH)D and prenatal growth $(38,39)$. However, several studies have found no relation between maternal 25(OH)D and offspring postnatal growth (40-45).

291 Conflicting results between studies may be related to geographical and genetic differences, leading to e.g. variable response to vitamin D supplementation $(46,47)$, and varying cut-offs applied for $25(\mathrm{OH}) \mathrm{D}$. Furthermore, it may be that only severe vitamin D deficiency $(<30 \mathrm{nmol} / \mathrm{L})(36,48)$, and, as suggested by our results, high 25(OH)D (>125 nmol/L) impair childhood growth. Vitamin D supplementation without vitamin D deficiency and "moderate" 25(OH)D concentrations would therefore not show associations with growth parameters. In our study, both maternal and child's 25(OH)D concentrations were at exceptionally high level compared with many other study cohorts.

298 This was due to widely used vitamin D supplementation during pregnancy and national vitamin D 299 food fortification $(49,50)$. In the VIDI cohort we have shown that genotype modifies individual's 25(OH)D and the response to vitamin D supplementation (47,51). This individual dose-response was 
shown in Group-30 but not in Group-10 (47), which might explain why we in the current study did not observe a similar relation between both vitamin D supplementation and vitamin D concentration and growth.

Severe vitamin D deficiency leads to growth impairment. If vitamin D indeed has an inverse Ushaped association with early growth, the mechanism how high $25(\mathrm{OH}) \mathrm{D}$ could disturb normal growth is unclear. Its role as a plasma calcium regulator could be one possible pathway. If high $25(\mathrm{OH}) \mathrm{D}$ leads to high circulating 1,25-dihydroxyvitamin $\mathrm{D}\left[1,25(\mathrm{OH})_{2} \mathrm{D}\right]$, this enhances calcium and phosphate resorption from bone to increase plasma calcium levels, thus possibly impairing growth (52). Based on one study, maternal $25(\mathrm{OH}) \mathrm{D}$ would not increase $1,25(\mathrm{OH})_{2} \mathrm{D}$ after $25(\mathrm{OH}) \mathrm{D}$ reaches the level of $100 \mathrm{nmol} / \mathrm{L}$ (53). However, many organs and tissues, like the growth plate, have the ability to produce $1,25(\mathrm{OH})_{2} \mathrm{D}$ locally $(54,55)$ and thus high $25(\mathrm{OH}) \mathrm{D}$ could lead to high local production of 1,25(OH)2D. In our cohort, at age 1 year, Infant 25(OH)D correlated with plasma calcium (56) and PTH concentrations (23). Furthermore, PTH levels were lower in Group-30 than Group-10 at age 1 year and 2 years. These observations suggest that vitamin D influenced the endocrine system. However, the intervention group did not affect measured bone parameters (22). Vitamin D may also affect growth-regulating hormones, e.g. insulin-like growth factor 1 (IGF-1) which may activate $1,25(\mathrm{OH})_{2} \mathrm{D}$ production $(57,58)$.

We have a large and homogenous sample of North-European subjects with longitudinal data from early pregnancy until child age of 2 years covering all seasons. Data were collected and processed in a standardized fashion in a single maternity hospital. However, subjects had more commonly a higher education and normal weight than nationally representative population. The small number of subjects having maternal $25(\mathrm{OH}) \mathrm{D}$ values in both extreme ends, and only few vitamin D insufficient children may have constrained our analyses. We applied multiple methods to discover the possible relation between vitamin $\mathrm{D}$ and childhood growth and adjusted for potential confounders. As we did not observe a direct effect of vitamin D supplementation but rather consistent associations between $25(\mathrm{OH}) \mathrm{D}$ and growth parameters, we cannot determine true direction of causality. However, interactions of absolute body size and vitamin D intake were not observed. 
328 The debate about the optimal 25(OH)D level for health outcomes is still ongoing $(59,60)$. Studies with 329 subjects of high 25(OH)D concentrations are scarce (61), especially in geographical locations with 330 limited solar radiation, hence our data with exceptionally high $25(\mathrm{OH}) \mathrm{D}$ values are of importance in 331 gaining more understanding about the relationship between vitamin $\mathrm{D}$ and health.

333 Conclusion

334 In this large study, high maternal and child 25(OH)D concentrations were associated with delayed 335 growth in 1- and 2-years old children, but infant vitamin D supplementation in itself had only a minor 336 impact on growth measures. Our results imply that vitamin D may have an inverse U-shaped relation 337 with childhood growth. Therefore, aiming for higher than sufficient 25(OH)D levels with high 338 vitamin D dosages may have undesired consequences on child growth. The clinical relevance of our 339 results, however, remains to be evaluated in future studies. 
344 We acknowledge the important work of our research nurses Sirpa Nolvi, Rhea Paajanen, Nea Boman

345 and Päivi Turunen, and laboratory technician Sari Lindén in data collection and analysis. We thank

346 the midwives and laboratory technicians at Kätilöopisto Maternity Hospital for obtaining umbilical

347 cord blood samples, and biostatistician Paula Bergman for her advice on statistical procedures

348 (University of Helsinki and Helsinki University Hospital). Foremost, we thank all the families that 349 participated in this study.

351 Data Availability

352

353 Some or all datasets generated during and/or analyzed during the current study are not publicly

354 available but are available from the corresponding author on reasonable request. 
1. Munns CF, Shaw N, Kiely M, Specker BL, Thacher TD, Ozono K, Michigami T, Tiosano D, Mughal MZ, Mäkitie O, Ramos-Abad L, Ward L, DiMeglio LA, Atapattu N, Cassinelli H, Braegger C, Pettifor JM, Seth A, Idris HW, Bhatia V, Fu J, Goldberg G, Sävendahl L, Khadgawat R, Pludowski P, Maddock J, Hyppönen E, Oduwole A, Frew E, Aguiar M, Tulchinsky T, Butler G, Högler W. Global Consensus Recommendations on Prevention and Management of Nutritional Rickets. The Journal of Clinical Endocrinology \& Metabolism 2016;101(2):394-415.

2. Amraei M, Mohamadpour S, Sayehmiri K, Mousavi SF, Shirzadpour E, Moayeri A. Effects of Vitamin D Deficiency on Incidence Risk of Gestational Diabetes Mellitus: A Systematic Review and Meta-analysis. Front. Endocrinol. 2018;9:7.

3. Bi WG, Nuyt AM, Weiler H, Leduc L, Santamaria C, Wei SQ. Association Between Vitamin D Supplementation During Pregnancy and Offspring Growth, Morbidity, and Mortality: A Systematic Review and Meta-analysis. JAMA Pediatr. 2018;172(7):635-645.

4. Tous M, Villalobos M, Iglesias L, Fernández-Barrés S, Arija V. Vitamin D status during pregnancy and offspring outcomes: a systematic review and meta-analysis of observational studies. Eur J Clin Nutr 2020;74(1):36-53.

5. Lips P, Cashman KD, Lamberg-Allardt C, Bischoff-Ferrari HA, Obermayer-Pietsch BR, Bianchi M, Stepan J, El-Hajj Fuleihan G, Bouillon R. MANAGEMENT OF ENDOCRINE DISEASE: Current vitamin D status in European and Middle East countries and strategies to prevent vitamin D deficiency; a position statement of the European Calcified Tissue Society. Eur.J.Endocrinol. 2019;(Journal Article). doi:10.1530/EJE-18-0736.

6. Ross AC, Manson JE, Abrams SA, Aloia JF, Brannon PM, Clinton SK, Durazo-Arvizu RA, Gallagher JC, Gallo RL, Jones G, Kovacs CS, Mayne ST, Rosen CJ, Shapses SA. The 2011 Report on Dietary Reference Intakes for Calcium and Vitamin D from the Institute of Medicine: What Clinicians Need to Know. The Journal of Clinical Endocrinology \& Metabolism 2011;96(1):53-58.

7. Cashman KD, Sheehy T, O'Neill CM. Is vitamin D deficiency a public health concern for low middle income countries? A systematic literature review. Eur J Nutr 2019;58(1):433-453.

8. Saraf R, Morton SMB, Camargo CA, Grant CC. Global summary of maternal and newborn vitamin D status - a systematic review: Global maternal and newborn vitamin D status. Maternal \& Child Nutrition 2016;12(4):647-668.

9. Syödään yhdessä - ruokasuositukset lapsiperheille. THL; 2019. Available at: http://www.julkari.fi/handle/10024/137459. Accessed August 10, 2020.

10. The WHO Reproductive Health Library. WHO recommendation regarding Vitamin D supplementation during pregnancy. 2016. Available at: https://extranet.who.int/rhl/topics/preconception-pregnancy-childbirth-and-postpartumcare/antenatal-care/who-recommendation-regarding-vitamin-d-supplementation-duringpregnancy.

11. Holick MF, Binkley NC, Bischoff-Ferrari HA, Gordon CM, Hanley DA, Heaney RP, Murad MH, Weaver CM, Endocrine Society. Evaluation, treatment, and prevention of vitamin D deficiency: an Endocrine Society clinical practice guideline. J.Clin.Endocrinol.Metab. 2011;96(7):19111930.

12. Wagner CL, Hollis BW. The Implications of Vitamin D Status During Pregnancy on Mother and her Developing Child. Front. Endocrinol. 2018;9:500. 
13. Pérez-López FR, Pilz S, Chedraui P. Vitamin D supplementation during pregnancy: an overview. Curr. Opin. Obstet. Gynecol. 2020. doi:10.1097/GCO.0000000000000641.

14. Santamaria C, Bi WG, Leduc L, Tabatabaei N, Jantchou P, Luo Z-C, Audibert F, Nuyt AM, Wei SQ. Prenatal vitamin D status and offspring's growth, adiposity and metabolic health: a systematic review and meta-analysis. Br J Nutr 2018;119(3):310-319.

15. Trilok-Kumar G, Kaur M, Rehman AM, Arora H, Rajput MM, Chugh R, Kurpad A, Sachdev HS, Filteau S. Effects of vitamin D supplementation in infancy on growth, bone parameters, body composition and gross motor development at age 3-6 years: follow-up of a randomized controlled trial. Int. J. Epidemiol. 2015;44(3):894-905.

16. Gallo S, Hazell T, Vanstone CA, Agellon S, Jones G, L'Abbe M, Rodd C, Weiler HA. Vitamin D supplementation in breastfed infants from Montreal, Canada: 25-hydroxyvitamin D and bone health effects from a follow-up study at 3 years of age. Osteoporos.Int. 2016;(Journal Article). doi:10.1007/s00198-016-3549-z.

17. Roth DE, Morris SK, Zlotkin S, Gernand AD, Ahmed T, Shanta SS, Papp E, Korsiak J, Shi J, Islam MM, Jahan I, Keya FK, Willan AR, Weksberg R, Mohsin M, Rahman QS, Shah PS, Murphy KE, Stimec J, Pell LG, Qamar H, Al Mahmud A. Vitamin D Supplementation in Pregnancy and Lactation and Infant Growth. N. Engl. J. Med. 2018;379(6):535-546.

18. Knop MR, Geng TT, Gorny AW, Ding R, Li C, Ley SH, Huang T. Birth Weight and Risk of Type 2 Diabetes Mellitus, Cardiovascular Disease, and Hypertension in Adults: A Meta-Analysis of 7646267 Participants From 135 Studies. J.Am.Heart Assoc. 2018;7(23):e008870.

19. Eriksson JG, Forsen TJ, Osmond C, Barker DJ. Pathways of infant and childhood growth that lead to type 2 diabetes. Diabetes Care 2003;26(11):3006-3010.

20. Lahti M, Räikkönen K, Wahlbeck K, Heinonen K, Forsén T, Kajantie E, Pesonen A-K, Osmond C, Barker DJP, Eriksson JG. Growth in Infancy and Childhood and Hospitalization for Personality Disorders in Adulthood: The Helsinki Birth Cohort Study. Journal of Personality Disorders 2011;25(5):620-633.

21. Helve O, Viljakainen H, Holmlund-Suila E, Rosendahl J, Hauta-alus H, Enlund-Cerullo M, Valkama S, Heinonen K, Raikkonen K, Hytinantti T, Makitie O, Andersson S. Towards evidence-based vitamin D supplementation in infants: vitamin D intervention in infants (VIDI) study design and methods of a randomised controlled double-blinded intervention study. BMC Pediatr. 2017;17(1):91-017-0845-5.

22. Rosendahl J, Valkama S, Holmlund-Suila E, Enlund-Cerullo M, Hauta-alus H, Helve O, Hytinantti T, Levälahti E, Kajantie E, Viljakainen H, Mäkitie O, Andersson S. Effect of Higher vs Standard Dosage of Vitamin D3 Supplementation on Bone Strength and Infection in Healthy Infants: A Randomized Clinical Trial. JAMA Pediatr 2018;172(7):646-654.

23. Hauta-alus HH, Kajantie E, Holmlund-Suila EM, Rosendahl J, Valkama SM, Enlund-Cerullo M, Helve OM, Hytinantti TK, Viljakainen H, Andersson S, Mäkitie O. High Pregnancy, Cord Blood, and Infant Vitamin D Concentrations May Predict Slower Infant Growth. J. Clin. Endocrinol. Metab. 2019;104(2):397-407.

24. Sankilampi U, Hannila M-L, Saari A, Gissler M, Dunkel L. New population-based references for birth weight, length, and head circumference in singletons and twins from 23 to 43 gestation weeks. Ann. Med. 2013;45(5-6):446-454. 
25. Saari A, Sankilampi U, Hannila M-L, Kiviniemi V, Kesseli K, Dunkel L. New Finnish growth references for children and adolescents aged 0 to 20 years: Length/height-for-age, weight-forlength/height, and body mass index-for-age. Annals of Medicine 2011;43(3):235-248.

26. Hauta-alus HH, Korkalo L, Holmlund-Suila EM, Rosendahl J, Valkama SM, Enlund-Cerullo M, Helve OM, Hytinantti TK, Makitie OM, Andersson S, Viljakainen HT. Food and Nutrient Intake and Nutrient Sources in 1-Year-Old Infants in Finland: A Cross-Sectional Analysis. Nutrients 2017;9(12):10.3390/nu9121309.

27. De Stavola BL, Nitsch D, dos Santos Silva I, McCormack V, Hardy R, Mann V, Cole TJ, Morton S, Leon DA. Statistical issues in life course epidemiology. Am.J.Epidemiol. 2006;163(1):84-96.

28. Arnberg K, Østergård M, Madsen A, Krarup H, Michaelsen K, Mølgaard C. Associations between vitamin D status in infants and blood lipids, body mass index and waist circumference: Vitamin D, lipids, BMI and waist circumference in infants. Acta Paediatrica 2011;100(9):12441248.

29. Holmlund-Suila E, Viljakainen H, Hytinantti T, Lamberg-Allardt C, Andersson S, Mäkitie O. High-dose vitamin d intervention in infants--effects on vitamin d status, calcium homeostasis, and bone strength. J.Clin.Endocrinol.Metab. 2012;97(11):4139-4147.

30. Mokhtar RR, Holick MF, Sempértegui F, Griffiths JK, Estrella B, Moore LL, Fox MP, Hamer DH. Vitamin D status is associated with underweight and stunting in children aged 6-36 months residing in the Ecuadorian Andes. Public Health Nutr 2018;21(11):1974-1985.

31. Rosendahl J, Holmlund-Suila E, Helve O, Viljakainen H, Hauta-alus H, Valkama S, EnlundCerullo M, Hytinantti T, Tervahartiala T, Sorsa T, Mäkitie O, Andersson S. 25-hydroxyvitamin D correlates with inflammatory markers in cord blood of healthy newborns. Pediatr Res 2017;81(5):731-735.

32. Rosendahl J, Pelkonen AS, Helve O, Hauta-alus H, Holmlund-Suila E, Valkama S, EnlundCerullo M, Viljakainen H, Hytinantti T, Mäkitie O, Andersson S, Mäkelä MJ. High-Dose Vitamin D Supplementation Does Not Prevent Allergic Sensitization of Infants. J. Pediatr. 2019;209:139-145.e1.

33. Zhu P, Tong SL, Hao JH, Tao RX, Huang K, Hu WB, Zhou QF, Jiang XM, Tao FB. Cord blood vitamin $\mathrm{D}$ and neurocognitive development are nonlinearly related in toddlers. J.Nutr. 2015;145(6):1232-1238.

34. Nwaru BI, Hadkhale K, Hämäläinen N, Takkinen H-M, Ahonen S, Ilonen J, Toppari J, Niemelä O, Haapala A-M, Veijola R, Knip M, Virtanen SM. Vitamin D intake during the first 4 years and onset of asthma by age 5: A nested case-control study. Pediatr Allergy Immunol 2017;28(7):641648 .

35. Leffelaar ER, Vrijkotte TG, van Eijsden M. Maternal early pregnancy vitamin D status in relation to fetal and neonatal growth: results of the multi-ethnic Amsterdam Born Children and their Development cohort. Br.J.Nutr. 2010;104(1):108-117.

36. Eckhardt CL, Gernand AD, Roth DE, Bodnar LM. Maternal vitamin D status and infant anthropometry in a US multi-centre cohort study. Ann.Hum.Biol. 2015;42(3):215-222.

37. Christensen ME, Beck-Nielsen SS, Dalgard C, Larsen SD, Lykkedegn S, Kyhl HB, Husby S, Christesen HT. A novel inverse association between cord 25-hydroxyvitamin D and leg length in boys up to three years. An Odense Child Cohort study. PLoS One 2018;13(6):e0198724. 
38. Bodnar LM, Catov JM, Zmuda JM, Cooper ME, Parrott MS, Roberts JM, Marazita ML, Simhan HN. Maternal serum 25-hydroxyvitamin D concentrations are associated with small-forgestational age births in white women. J.Nutr. 2010;140(5):999-1006.

39. Zhu P, Tong SL, Hu WB, Hao JH, Tao RX, Huang K, Mou Z, Zhou QF, Jiang XM, Tao FB. Cord Blood 25-hydroxyvitamin D and Fetal Growth in the China-Anhui Birth Cohort Study. Sci.Rep. 2015;5(Journal Article):14930.

40. Sauder K, Koeppen H, Shapiro A, Kalata K, Stamatoiu A, Ringham B, Glueck D, Norris J, Dabelea D. Prenatal Vitamin D Intake, Cord Blood 25-Hydroxyvitamin D, and Offspring Body Composition: The Healthy Start Study. Nutrients 2017;9(7):790.

41. Gale CR, Robinson SM, Harvey NC, Javaid MK, Jiang B, Martyn CN, Godfrey KM, Cooper C, Princess Anne Hospital Study Group. Maternal vitamin D status during pregnancy and child outcomes. Eur.J.Clin.Nutr. 2008;62(1):68-77.

42. Egge S, Christensen N, Lykkedegn S, Jensen TK, Christesen HT. Cord serum 25-hydroxyvitamin $\mathrm{D}$ is not associated with cranial anthropometrics in infants up to 6 months of age. An Odense Child Cohort study. J.Bone Miner.Metab. 2017;(Journal Article). doi:10.1007/s00774-017-08810 .

43. Vieth Streym S, Kristine Moller U, Rejnmark L, Heickendorff L, Mosekilde L, Vestergaard P. Maternal and infant vitamin D status during the first 9 months of infant life-a cohort study. Eur.J.Clin.Nutr. 2013;67(10):1022-1028.

44. Larsen SD, Christensen ME, Dalgard C, Lykkedegn S, Andersen LB, Andersen MS, Glintborg D, Christesen HT. Pregnancy or cord 25-hydroxyvitamin D is not associated with measures of body fat or adiposity in children from three months to three years of age. An Odense Child Cohort study. Clin.Nutr. 2019;(Journal Article).

45. Gould JF, Anderson AJ, Yelland LN, Smithers LG, Skeaff CM, Zhou SJ, Gibson RA, Makrides M. Association of cord blood vitamin D with early childhood growth and neurodevelopment. J.Paediatr.Child Health 2017;53(1):75-83.

46. Powe CE, Evans MK, Wenger J, Zonderman AB, Berg AH, Nalls M, Tamez H, Zhang D, Bhan I, Karumanchi SA, Powe NR, Thadhani R. Vitamin D-binding protein and vitamin D status of black Americans and white Americans. N. Engl. J. Med. 2013;369(21):1991-2000.

47. Enlund-Cerullo M, Koljonen L, Holmlund-Suila E, Hauta-alus H, Rosendahl J, Valkama S, Helve O, Hytinantti T, Viljakainen H, Andersson S, Mäkitie O, Pekkinen M. Genetic Variation of the Vitamin D Binding Protein Affects Vitamin D Status and Response to Supplementation in Infants. J. Clin. Endocrinol. Metab. 2019;104(11):5483-5498.

48. Ong YL, Quah PL, Tint MT, Aris IM, Chen LW, van Dam RM, Heppe D, Saw SM, Godfrey KM, Gluckman PD, Chong YS, Yap F, Lee YS, Foong-Fong Chong M. The association of maternal vitamin D status with infant birth outcomes, postnatal growth and adiposity in the first 2 years of life in a multi-ethnic Asian population: the Growing Up in Singapore Towards healthy Outcomes (GUSTO) cohort study. Br.J.Nutr. 2016;(Journal Article):1-11.

49. Hauta-alus HH, Holmlund-Suila EM, Rita HJ, Enlund-Cerullo M, Rosendahl J, Valkama SM, Helve OM, Hytinantti TK, Surcel HM, Makitie OM, Andersson S, Viljakainen HT. Season, dietary factors, and physical activity modify 25 -hydroxyvitamin D concentration during pregnancy. Eur.J.Nutr. 2017;DOI 10.1007/s00394-017-1417-z(Journal Article). doi:10.1007/s00394-017-1417-z. 
50. Jääskelainen T, Itkonen ST, Lundqvist A, Erkkola M, Koskela T, Lakkala K, Dowling KG, Hull GL, Kroger H, Karppinen J, Kyllönen E, Harkanen T, Cashman KD, Männistö S, LambergAllardt C. The positive impact of general vitamin D food fortification policy on vitamin D status in a representative adult Finnish population: evidence from an 11-y follow-up based on standardized 25-hydroxyvitamin D data. Am.J.Clin.Nutr. 2017;105(6):1512-1520.

51. Kämpe A, Enlund-Cerullo M, Valkama S, Holmlund-Suila E, Rosendahl J, Hauta-alus H, Pekkinen M, Andersson S, Mäkitie O. Genetic variation in GC and CYP2R1 affects 25hydroxyvitamin D concentration and skeletal parameters: A genome-wide association study in 24-month-old Finnish children. PLoS Genet. 2019;15(12):e1008530.

52. Goltzman D. Functions of vitamin D in bone. Histochem.Cell Biol. 2018;149(4):305-312.

53. Hollis BW, Johnson D, Hulsey TC, Ebeling M, Wagner CL. Vitamin D supplementation during pregnancy: double-blind, randomized clinical trial of safety and effectiveness. J.Bone Miner.Res. 2011;26(10):2341-2357.

54. Norman AW. From vitamin D to hormone D: fundamentals of the vitamin D endocrine system essential for good health. Am.J.Clin.Nutr. 2008;88(2):491S-499S.

55. St-Arnaud R. The direct role of vitamin D on bone homeostasis. Arch. Biochem. Biophys. 2008;473(2):225-230.

56. Valkama S, Holmlund-Suila E, Enlund-Cerullo M, Rosendahl J, Hauta-alus H, Helve O, Hytinantti T, Viljakainen H, Andersson S, Makitie O. No Severe Hypercalcemia with Daily Vitamin D3 Supplementation of up to 30 microg during the First Year of Life. Horm.Res.Paediatr. 2017;88(2):147-154.

57. Mortensen C, Mølgaard C, Hauger H, Kristensen M, Damsgaard CT. Winter vitamin D3 supplementation does not increase muscle strength, but modulates the IGF-axis in young children. Eur J Nutr 2019;58(3):1183-1192.

58. Esposito S, Leonardi A, Lanciotti L, Cofini M, Muzi G, Penta L. Vitamin D and growth hormone in children: a review of the current scientific knowledge. J Transl Med 2019;17(1):87.

59. Cashman KD, Kiely M. Nutrition: new guidelines on vitamin D-ficiency--clear or confusing? Nat.Rev.Endocrinol. 2011;7(10):566-568.

60. Kiely ME, Wagner CL, Roth DE. Vitamin D in pregnancy: Where we are and where we should go. The Journal of Steroid Biochemistry and Molecular Biology 2020;201:105669.

61. Durazo-Arvizu RA, Dawson-Hughes B, Kramer H, Cao G, Merkel J, Coates PM, Sempos CT. The Reverse J-Shaped Association Between Serum Total 25-Hydroxyvitamin D Concentration and All-Cause Mortality: The Impact of Assay Standardization. Am. J. Epidemiol. 2017;185(8):720-726. 
562 Figure 1 Mean $(95 \% \mathrm{Cl})$ values of conditional growth at 1 year of age, i.e. growth rate,

according to intervention groups. Conditional growth at 1 year refers to the difference of body size at 1 year with expected based on body size at birth and 6 months, expressed in standardized residuals, SD units. Statistical difference tested with Independent-Samples $T$ test. Number of subjects for length and length-adjusted weight: $10 \mu \mathrm{g}, \mathrm{n}=401 ; 30 \mu \mathrm{g}, \mathrm{n}=410$, for weight: $10 \mu \mathrm{g}, \mathrm{n}=402 ; 30 \mu \mathrm{g}, \mathrm{n}=410$, and for head circumference: $10 \mu \mathrm{g}, \mathrm{n}=387 ; 30 \mu \mathrm{g}$, $n=394$.

Figure 2 Mean $(95 \% \mathrm{Cl})$ values of conditional growth at 2 years of age, i.e. growth rate, according to intervention groups. Conditional growth at 2 years refers to the difference of body size at 2 years with expected based on body size at birth, 6 months and 1 year, expressed in standardized residuals, SD units. Statistical difference tested with Independent-Samples $T$ test. Number of subjects for length: $10 \mu \mathrm{g}, \mathrm{n}=401 ; 30 \mu \mathrm{g}, \mathrm{n}=410$, for weight: $10 \mu \mathrm{g}, \mathrm{n}=401 ; 30$ $\mu \mathrm{g}, \mathrm{n}=409$, for length-adjusted weight: $10 \mu \mathrm{g}, \mathrm{n}=400 ; 30 \mu \mathrm{g}, \mathrm{n}=409$, and for head circumference: $10 \mu \mathrm{g}, \mathrm{n}=380 ; 30 \mu \mathrm{g}, \mathrm{n}=387$.

Figure 3 Pregnancy 25(OH)D and offspring growth measures at 2 years of age. Symbols present adjusted mean $(95 \% \mathrm{Cl})$ values of growth measures in Pregnancy $25(\mathrm{OH}) \mathrm{D}$ categories of $<50 \mathrm{nmol} / \mathrm{L}$ $(n=24), 50-74.9 \mathrm{nmol} / \mathrm{L}(\mathrm{n}=220)$ (reference group), $75-125 \mathrm{nmol} / \mathrm{L}(\mathrm{n}=420)$ and $>125 \mathrm{nmol} / \mathrm{L}(\mathrm{n}=16)$. Adjustments are for corresponding birth size SDS, maternal and paternal height z-scores and intervention group. Statistical difference tested with linear regression with 50-74.9 nmol/L applied as a reference group. 25(OH)D, 25-hydroxy vitamin D; SDS, SD-score, based on Finnish sex- and agespecific normative data for infant growth; Length/weight, length-adjusted weight, HC, head circumference; MUAC, mid-upper-arm circumference (in z-score); BMI, body mass index (in z-score). The reference group's symbol has been highlighted.

Figure 4 Umbilical cord blood (UCB) 25(OH)D and offspring growth measures at 2 years of age. Symbols present adjusted mean $(95 \% \mathrm{Cl})$ values of growth measures in UCB $25(\mathrm{OH}) \mathrm{D}$ categories of $<50 \mathrm{nmol} / \mathrm{L}(\mathrm{n}=27), 50-74.9 \mathrm{nmol} / \mathrm{L}(\mathrm{n}=304)$ (reference group), $75-125 \mathrm{nmol} / \mathrm{L}(\mathrm{n}=429)$ and $>125$ $\mathrm{nmol} / \mathrm{L}(\mathrm{n}=34)$. Adjustments are for corresponding birth size SDS, maternal and paternal height $\mathrm{z}$ scores and intervention group. Statistical difference tested with linear regression with $50-74.9 \mathrm{nmol} / \mathrm{L}$ applied as a reference group. 25(OH)D, 25-hydroxy vitamin D; SDS, SD-score, based on Finnish sexand age-specific normative data for infant growth; Length/weight, length-adjusted weight, HC, head circumference; MUAC, mid-upper-arm circumference (in z-score); BMI, body mass index (in z-score). The reference group's symbol has been highlighted.

Figure 5 Toddler 25(OH)D and offspring growth measures at 2 years of age. Symbols present adjusted mean $(95 \% \mathrm{Cl})$ values of growth measures in Toddler $25(\mathrm{OH}) \mathrm{D}$ categories of $<75 \mathrm{nmol} / \mathrm{L}$ $(n=138)$ (reference group), $75-125 \mathrm{nmol} / \mathrm{L}(\mathrm{n}=502)$ and $>125 \mathrm{nmol} / \mathrm{L}(\mathrm{n}=172)$. Adjustments are for corresponding birth size SDS, maternal and paternal height z-scores and intervention group. Statistical difference tested with linear regression with $<75 \mathrm{nmol} / \mathrm{L}$ applied as a reference group. 25(OH)D, 25-hydroxy vitamin D; SDS, SD-score, based on Finnish sex- and age-specific normative data for infant growth; Length/weight, length-adjusted weight, HC, head circumference; MUAC, midupper-arm circumference (in z-score); BMI, body mass index (in z-score). The reference group's symbol has been highlighted.

Figure 6 Toddler 25(OH)D in quartiles and offspring growth measures at 2 years of age. Symbols present adjusted mean $(95 \% \mathrm{Cl})$ values of growth measures in Toddler $25(\mathrm{OH}) \mathrm{D}$ quartiles of 1 . quartile $(<81.2 \mathrm{nmol} / \mathrm{L}, \mathrm{n}=203$ ) (reference group), 2. quartile (81.2-99.2 nmol/L, $\mathrm{n}=203)$, 3. quartile (99.3-120.7 $\mathrm{nmol} / \mathrm{L}, \mathrm{n}=204)$ and 4 . quartile $(>121 \mathrm{nmol} / \mathrm{L}, \mathrm{n}=202)$. Adjustments are for corresponding birth size SDS, maternal and paternal height z-scores and intervention group. Statistical difference tested with linear regression with 1 . quartile applied as a reference group. $25(\mathrm{OH}) \mathrm{D}, 25$-hydroxy vitamin $\mathrm{D}$; SDS, SD-score, based on Finnish sex- and age-specific normative data for infant growth; Length/weight, length-adjusted weight, $\mathrm{HC}$, head circumference; MUAC, mid-upper-arm circumference; BMI, body 587 
590 Table 1 Family characteristics according to intervention groups

\begin{tabular}{lccc}
\hline & $\begin{array}{c}\text { Group-10 } \\
\mathrm{n}=402\end{array}$ & $\begin{array}{c}\text { Group-30 } \\
\mathrm{n}=410\end{array}$ & P value \\
\hline Maternal age, year & $31.4(4.0)$ & $31.9(4.5)$ & 0.10 \\
Paternal age, yeara & $32.9(5.0)$ & $33.7(5.8)$ & $\mathbf{0 . 0 2 6}$ \\
Maternal height, cm & $166.3(6.1)$ & $166.3(5.9)$ & 0.94 \\
Paternal height, cm ${ }^{\mathrm{b}}$ & $180.7(6.7)$ & $180.2(6.6)$ & 0.36 \\
Maternal prepregnancy BMIc & $23.2(3.7)$ & $23.3(3.7)$ & 0.64 \\
Paternal BMId & $26.0(3.5)$ & $25.6(3.2)$ & $\mathbf{0 . 0 4 8}$ \\
Pregnancy 25(OH)D, nmol/Le & $82.9(21.9)$ & $81.8(17.8)$ & 0.49 \\
Pregnancy sampling, gestational & $11.3(2.2)$ & $11.5(3.3)$ & 0.39 \\
week & & & \\
Maternal supplemental vitamin D & $17.1(19.8)$ & $14.6(12.8)$ & 0.26 \\
intake, $\mu$ g/d & $15(61 / 399)$ & $16(66 / 409)$ & 0.74 \\
Maternal smoking, yes, \% (n) & $26(102 / 397)$ & $25(100 / 404)$ & 0.76 \\
Paternal smoking, yes, \% (n) & $81(322 / 397)$ & $84(345 / 410)$ & 0.26 \\
Parental education, higher, \% (n) & & & 0.24 \\
Family income level & & & \\
$<40000 € /$ year, \% $(\mathrm{n})$ & $16(64)$ & $18(70)$ & \\
$40000-89000 € /$ year, \% $(\mathrm{n})$ & $59(231)$ & $54(216)$ & 591 \\
$>90000 € /$ year, \% $(\mathrm{n})$ & $20(79)$ & $20(81)$ & 592 \\
Don't know & $5(18)$ & $8(31)$ & 593 \\
\hline
\end{tabular}

594 Values are means (SD) and P values are based on Independent-Samples T test, Mann-Whitney U 595 test or Chi-Square.

596 a9 missing values; b16 missing values; ‘ 4 missing values; ${ }^{2} 24$ missing values; ${ }^{\text {e }} 132$ missing values; ’ 22 missing

597 values.

598

599

600

601

602 
Table 2 Infant growth parameters from birth to 2 years of age according to intervention groups

\begin{tabular}{|c|c|c|c|}
\hline & $\begin{array}{c}\text { Group }-10 \\
n=402\end{array}$ & $\begin{array}{c}\text { Group-30 } \\
n=410\end{array}$ & $P$ value \\
\hline \multicolumn{4}{|l|}{ At birth } \\
\hline Gestational age, wk & $40.1(1.1)$ & $40.2(1.1)$ & 0.08 \\
\hline Length, $\mathrm{cm}$ & $50.3(1.7)$ & $50.4(1.8)$ & 0.35 \\
\hline Length, SDS & $-0.12(0.89)$ & $-0.11(0.92)$ & 0.86 \\
\hline Weight, kg & $3.50(0.37)$ & $3.56(0.40)$ & 0.027 \\
\hline Weight, SDS & $-0.19(0.79)$ & $-0.12(0.84)$ & 0.17 \\
\hline Length-adjusted weight, SDS & $0.02(0.93)$ & $0.14(0.93)$ & 0.08 \\
\hline Head circumference, $\mathrm{cm}^{\mathrm{a}}$ & $35.2(1.4)$ & $35.2(1.4)$ & 0.45 \\
\hline Head circumference, SDS ${ }^{a}$ & $0.19(1.04)$ & $0.08(1.02)$ & 0.12 \\
\hline $\begin{array}{l}\text { UCB 25(OH)D, nmol/L } \\
\text { [range] }^{\mathrm{b}}\end{array}$ & $\begin{array}{c}83.4(28.2) \\
{[36.7-283.7]}\end{array}$ & $\begin{array}{c}81.8(23.5) \\
{[37.8-229.0]}\end{array}$ & 0.39 \\
\hline \multicolumn{4}{|l|}{ At 1 year of age } \\
\hline Age at follow-up, y & $1.00(0.03)$ & $1.00(0.03)$ & 0.93 \\
\hline Length, $\mathrm{cm}^{\mathrm{a}}$ & $75.4(2.6)$ & $75.2(2.5)$ & 0.19 \\
\hline Length, SDSa & $-0.49(1.0)$ & $-0.59(0.98)$ & 0.14 \\
\hline Weight, kg & $9.8(1.2)$ & $9.8(1.1)$ & 0.44 \\
\hline Weight, SDS & $-0.19(1.0)$ & $-0.24(0.99)$ & 0.48 \\
\hline Length-adjusted weight, SDSa & $0.04(1.0)$ & $0.04(1.0)$ & 0.94 \\
\hline Head circumference, $\mathrm{cm}^{\mathrm{e}}$ & $46.6(1.2)$ & $46.4(1.2)$ & 0.08 \\
\hline Head circumference, SDSe & $-0.32(0.97)$ & $-0.45(0.93)$ & 0.053 \\
\hline MUAC, $\mathrm{mm}^{\dagger}$ & $152.7(12.9)$ & $153.0(11.8)$ & 0.69 \\
\hline MUAC $^{2}, z$-score ${ }^{f}$ & $-0.02(1.0)$ & $0.02(0.96)$ & 0.66 \\
\hline $\begin{array}{l}\text { Blood } 25(\mathrm{OH}) \mathrm{D}, \mathrm{nmol} / \mathrm{L} \\
\text { [range] }^{\mathrm{g}}\end{array}$ & $\begin{array}{l}82.8(19.9) \\
{[37.0-140.0]}\end{array}$ & $\begin{array}{l}116.0(27.6) \\
{[51.8-241.0]}\end{array}$ & $<0.001$ \\
\hline Vitamin D intake from food, $\mu \mathrm{g} / \mathrm{day}^{\mathrm{h}}$ & $6.3(3.7)$ & $6.1(3.7)$ & 0.38 \\
\hline Compliance, \% ${ }^{i}$ & $90.1(10.4)$ & $89.4(10.6)$ & 0.48 \\
\hline $\begin{array}{l}\text { Supplemental vitamin D intake, } \\
\text { compliance based } \mu \mathrm{g} / \mathrm{day} \mathrm{i}^{\mathrm{i}}\end{array}$ & $9.0(1.0)$ & $26.8(3.2)$ & $<0.001$ \\
\hline Energy intake, MJ/day ${ }^{h}$ & $3.36(0.9)$ & $3.31(0.9)$ & 0.26 \\
\hline \multicolumn{4}{|l|}{ At 2 years of age } \\
\hline Age at follow-up, y & $1.99(0.03)$ & $1.99(0.03)$ & 0.27 \\
\hline Length, $\mathrm{cm}$ & $87.8(3.2)$ & $87.7(3.0)$ & 0.77 \\
\hline Length, SDS & $-0.24(1.04)$ & $-0.27(1.0)$ & 0.71 \\
\hline Weight, kgd & $12.5(1.4)$ & $12.6(1.4)$ & 0.44 \\
\hline Weight, SDS ${ }^{d}$ & $-0.19(0.98)$ & $-0.14(0.99)$ & 0.47 \\
\hline Length-adjusted weight, SDS ${ }^{d}$ & $-0.12(0.98)$ & $-0.02(0.98)$ & 0.15 \\
\hline Head circumference, $\mathrm{cm}^{\mathrm{j}}$ & $49.1(1.3)$ & $49.1(1.3)$ & 0.60 \\
\hline Head circumference, SDSj & $-0.22(1.0)$ & $-0.26(0.98)$ & 0.56 \\
\hline MUAC, $\mathrm{mm}^{\mathrm{k}}$ & $161.8(11.2)$ & $162.5(12.2)$ & 0.42 \\
\hline MUAC, z-score ${ }^{k}$ & $-0.03(0.95)$ & $0.03(1.04)$ & 0.40 \\
\hline $\mathrm{BMI}, \mathrm{kg} / \mathrm{m}^{2 \mathrm{~d}}$ & $16.2(1.2)$ & $16.3(1.2)$ & 0.15 \\
\hline BMI, z-score ${ }^{d}$ & $-0.05(0.99)$ & $0.05(1.01)$ & 0.14 \\
\hline
\end{tabular}


Blood 25(OH)D, nmol/L [range]

Compliance, \%'

Compliance based supplemental vitamin

D intake, $\mu \mathrm{g} /$ day $^{\prime}$

Duration of breastfeeding, months ${ }^{m}$
$86.5(19.7)$

[42.4-153.5]

$117.7(26.1)$

[56.5-207.4]

$86.6(16.2)$

$85.5(17.7)$

0.73

$8.7(1.6)$

$25.6(5.3)$

$10.7(5.7)$

$11.0(5.6)$

$<0.001$

0.44
607

608

609

610

611

612

613

614

615

616

617

618

619

620

621

Values are means (SD). $P$ values are based on Independent-Samples T test or Mann-Whitney $U$ test. SDS, standard deviation score, based on Finnish sex- and age-specific normative data for infant growth; UCB, umbilical cord blood; 25(OH)D, blood 25-hydroxyvitamin D concentration; MUAC, midupper-arm circumference; BMI, body mass index.

a1 missing value; ${ }^{b} 18$ missing values; ' 22 missing values; ${ }^{d} 2$ missing values; ${ }^{\circ} 7$ missing values; ${ }^{\text {}} 34$ missing values; 958 missing values; ${ }^{\text {h}} 107$ missing values, breast milk intake not included; ${ }^{i} 10$ values missing; ${ }^{j} 14$ missing values; ${ }^{k} 17$ missing values; '20 values missing; ${ }^{\mathrm{m}} 6$ values missing, duration of breastfeeding was set to 2 years if still ongoing at 2 years' follow-up 
Table 3 Associations between Maternal 25(OH)D concentrations and offspring's growth measures at 2-years' follow-up visit

\begin{tabular}{|c|c|c|c|c|c|c|}
\hline \multirow[b]{2}{*}{$\begin{array}{l}\text { Pregnancy 25(OH)D, } 10 \mathrm{nmol} / \mathrm{L}, \\
\mathrm{n}=680\end{array}$} & \multicolumn{4}{|c|}{ SDS } & \multicolumn{2}{|c|}{ z-score } \\
\hline & Length & Weight & $\begin{array}{l}\text { Length-adjusted } \\
\text { weight }\end{array}$ & Head circumference & MUAC & $\mathrm{BMI}$ \\
\hline Model 1, unadjusted & $-0.01(-0.05,0.02)$ & $-0.02(-0.06,0.02)$ & $-0.02(-0.05,0.02)$ & $-0.00(-0.04,0.04)$ & $-0.03(-0.07,0.01)$ & $-0.02(-0.05,0.02)$ \\
\hline$P$ value & 0.48 & 0.29 & 0.38 & 0.97 & 0.12 & 0.42 \\
\hline Model 2, adjusted ${ }^{\mathrm{a}}$ & $-0.02(-0.05,0.02)$ & $-0.02(-0.06,0.01)$ & $-0.00(-0.00,-0.00)$ & $0.00(-0.02,0.02)$ & $-0.03(-0.07,0.00)$ & $-0.02(-0.05,0.02)$ \\
\hline$P$ value & 0.29 & 0.16 & 0.33 & 0.97 & 0.11 & 0.37 \\
\hline \multicolumn{7}{|l|}{ UCB 25(OH)D, $10 \mathrm{nmol} / \mathrm{L}, \mathrm{n}=794$} \\
\hline Model 1 , unadjusted & $0.01(-0.02,0.03)$ & $-0.01(-0.04,0.02)$ & $-0.02(-0.05,0.01)$ & $-0.01(-0.04,0.02)$ & $0.00(-0.02,0.03)$ & $-0.02(-0.05,0.00)$ \\
\hline$P$ value & 0.67 & 0.43 & 0.13 & 0.40 & 0.80 & 0.09 \\
\hline Model 2, adjusted ${ }^{a}$ & $0.00(-0.02,0.03)$ & $-0.01(-0.03,0.02)$ & $-0.02(-0.04,0.01)$ & $0.01(-0.02,0.03)$ & $0.01(-0.01,0.02)$ & $-0.02(-0.04,0.01)$ \\
\hline$P$ value & 0.72 & 0.60 & 0.24 & 0.69 & 0.65 & 0.19 \\
\hline
\end{tabular}

Values are beta coefficients $(95 \% \mathrm{Cl})$ per $10 \mathrm{nmol} / \mathrm{L}$ increase in $25(\mathrm{OH}) \mathrm{D}$ concentration based on linear regression.

SDS, standard deviation score, based on Finnish sex- and age-specific normative data for infant growth; 25(OH)D, blood 25-hydroxyvitamin D concentration; MUAC, mid-upperarm circumference; BMI, body mass index; UCB, umbilical cord blood.

aModel 2 is adjusted for the corresponding birth size SDS (except for MUAC and BMI; the covariate was length-adjusted birth weight), maternal and paternal height z-scores, and intervention group.

Missing values: in Pregnancy 25(OH)D analyses: 1 value missing in weight, length-adjusted weight and BMI; 12 values missing from head circumference and MUAC, in UCB 25(OH)D analyses: 2 values missing in weight, length-adjusted weight and BMI; 15 values missing from head circumference and MUAC. 
Table 4 Associations between Maternal and Toddler 25(OH)D and conditional growth at 2 years' follow-up visit

\begin{tabular}{|c|c|c|c|c|c|}
\hline & \multicolumn{5}{|c|}{ SD unit } \\
\hline $\begin{array}{l}\text { Pregnancy } 25(\mathrm{OH}) \mathrm{D}, 10 \mathrm{nmol} / \mathrm{L}, \\
\mathrm{n}=679\end{array}$ & Length & Weight & $\begin{array}{l}\text { Length-adjusted } \\
\text { weight }\end{array}$ & Head circumference & MUAC \\
\hline Model 1, unadjusted & $-0.01(-0.05,0.03)$ & $0.00(-0.04,0.03)$ & $0.01(-0.03,0.04)$ & $0.04(0.00,0.08)$ & $0.00(-0.04,0.03)$ \\
\hline$P$ value for linear association & 0.64 & 0.83 & 0.78 & 0.036 & 0.83 \\
\hline$P$ value for linear association & 0.65 & 0.81 & 0.74 & 0.037 & 0.80 \\
\hline \multicolumn{6}{|l|}{ UCB 25(OH)D, $10 \mathrm{nmol} / \mathrm{L}, \mathrm{n}=793$} \\
\hline Model 1 , unadjusted & $0.02(-0.01,0.04)$ & $0.00(-0.03,0.02)$ & $-0.02(-0.04,0.01)$ & $0.03(0.01,0.06)$ & $0.01(-0.01,0.04)$ \\
\hline$P$ value for linear association & 0.23 & 0.74 & 0.20 & 0.015 & 0.30 \\
\hline Model 2 , adjusted ${ }^{\mathrm{a}}$ & $0.01(-0.01,0.04)$ & $-0.01(-0.03,0.02)$ & $-0.02(-0.04,0.01)$ & $0.03(0.01,0.06)$ & $0.02(-0.01,0.04)$ \\
\hline$P$ value for linear association & 0.27 & 0.61 & 0.19 & 0.014 & 0.25 \\
\hline \multicolumn{6}{|l|}{$\begin{array}{l}\text { Toddler } 25(\mathrm{OH}) \mathrm{D} \text { at } 2 \text { years, } 10 \\
\mathrm{nmol} / \mathrm{L}, \mathrm{n}=\mathbf{8 1 1}\end{array}$} \\
\hline Model 1 , unadjusted & $0.01(-0.01,0.04)$ & $0.02(0.00,0.05)$ & $0.01(-0.01,0.04)$ & $0.01(-0.01,0.04)$ & $-0.01(-0.03,0.02)$ \\
\hline$P$ value for linear association & 0.40 & 0.072 & 0.34 & 0.30 & 0.59 \\
\hline Model 2, adjusted ${ }^{\mathrm{a}}$ & $0.00(-0.03,0.03)$ & $0.01(-0.02,0.04)$ & $0.00(-0.03,0.03)$ & $0.01(-0.02,0.04)$ & $-0.02(-0.05,0.01)$ \\
\hline$P$ value for linear association & 0.82 & 0.60 & 0.82 & 0.48 & 0.32 \\
\hline
\end{tabular}

Values are beta coefficients $(95 \% \mathrm{Cl})$ per $10 \mathrm{nmol} / \mathrm{L}$ increase in $25(\mathrm{OH}) \mathrm{D}$ concentration based on linear regression. Conditional growth refers to the difference of body size at 2 years with expected based on body size at birth, 6 months and 1 year, expressed in standardized residuals, SD units.

25(OH)D, 25-hydroxyvitamin D concentration; UCB, umbilical cord blood.

aModel 2 is adjusted for maternal and paternal height $z$-scores, and intervention group.

Missing values: in Pregnancy 25(OH)D analyses: 1 value missing in length-adjusted weight; 40 values missing from head circumference; 32 values missing from MUAC, in UCB 25(OH)D analyses: 1 value missing in length; 2 values missing length-adjusted weight; 42 values missing from head circumference; 44 values missing from MUAC, in Toddler $25(\mathrm{OH}) \mathrm{D}$ analyses: 1 value missing in lengthadjusted weight; 2 values missing from length-adjusted weight; 44 values missing from head circumference; 46 values missing from MUAC. 
Table 5 Associations between Infant 25(OH)D concentrations and growth measures at 1-year's follow-up visit stratified by 624

\section{intervention group}

\begin{tabular}{|c|c|c|c|c|c|}
\hline \multirow[b]{2}{*}{ Infant $25(\mathrm{OH}) \mathrm{D}, 10 \mathrm{nmol} / \mathrm{L}$} & \multicolumn{4}{|c|}{ SDS } & \multirow{2}{*}{$\frac{\text { z-score }}{\text { MUAC }}$} \\
\hline & Length & Weight & $\begin{array}{c}\text { Length-adjusted } \\
\text { weight }\end{array}$ & Head circumference & \\
\hline \multicolumn{6}{|l|}{ Group-10, $n=371$} \\
\hline Model 1, unadjusted & $0.02(-0.03,0.07)$ & $0.01(-0.04,0.06)$ & $0.00(-0.05,0.05)$ & $-0.01(-0.06,0.04)$ & $-0.01(-0.07,0.04)$ \\
\hline$P$ value & 0.47 & 0.69 & 0.95 & 0.79 & 0.68 \\
\hline Model 2, adjusted ${ }^{\mathrm{a}}$ & $0.02(-0.03,0.07)$ & $0.02(-0.03,0.07)$ & $0.00(-0.05,0.06)$ & $0.00(-0.05,0.04)$ & $-0.01(-0.06,0.05)$ \\
\hline$P$ value & 0.39 & 0.54 & 0.92 & 0.96 & 0.77 \\
\hline \multicolumn{6}{|l|}{ Group-30, n=383 } \\
\hline Model 1, unadjusted & $-0.04(-0.07,0.00)$ & $-0.07(-0.10,-0.03)$ & $-0.06(-0.10,-0.02)$ & $-0.04(-0.07,0.00)$ & $-0.04(-0.08,0.00)$ \\
\hline$P$ value & 0.047 & $<0.001$ & 0.001 & 0.039 & 0.026 \\
\hline Model 2, adjusted ${ }^{\mathrm{a}}$ & $-0.02(-0.05,0.01)$ & $-0.05(-0.09,-0.02)$ & $-0.06(-0.10,-0.02)$ & $-0.02(-0.05,0.01)$ & $-0.04(-0.08,-0.01)$ \\
\hline$P$ value & 0.17 & 0.001 & 0.001 & 0.19 & 0.022 \\
\hline
\end{tabular}

Values are beta coefficients $(95 \% \mathrm{Cl})$ per $10 \mathrm{nmol} / \mathrm{L}$ increase in $25(\mathrm{OH}) \mathrm{D}$ concentration based on linear regression.

SDS, standard deviation score, based on Finnish sex- and age-specific normative data for infant growth; 25(OH)D, blood 25-hydroxyvitamin D concentration; MUAC, mid-upper-arm circumference.

aModel 2 is adjusted for the corresponding birth size SDS (except for MUAC; the covariate was length-adjusted birth weight), maternal and paternal height z-scores and intervention group (except in analyses stratified by intervention groups).

Missing values: 1 value missing from length and length-adjusted weight; 5 values missing from head circumference; 32 values missing from MUAC. 
Table 6 Associations between Toddler 25(OH)D concentrations and growth measures at 2-years' follow-up visit stratified by intervention group

\begin{tabular}{|c|c|c|c|c|c|c|}
\hline \multirow[b]{2}{*}{$\begin{array}{l}\text { Toddler 25(OH)D, } 10 \\
\mathrm{nmol} / \mathrm{L}\end{array}$} & \multicolumn{4}{|c|}{ SDS } & \multicolumn{2}{|c|}{ z-score } \\
\hline & Length & Weight & $\begin{array}{c}\text { Length-adjusted } \\
\text { weight }\end{array}$ & $\begin{array}{c}\text { Head } \\
\text { circumference }\end{array}$ & MUAC & BMI \\
\hline \multicolumn{7}{|l|}{ All, $n=812$} \\
\hline Model 1, unadjusted & $-0.02(-0.05,0.00)$ & $-0.03(-0.06,-0.01)$ & $-0.03(-0.05,0.00)$ & $-0.01(-0.04,0.00)$ & $-0.02(-0.04,0.01)$ & $-0.03(-0.06,0.00)$ \\
\hline $\begin{array}{l}\text { P value } \\
\text { Model? }\end{array}$ & $\begin{array}{c}0.057 \\
-003(-0.05000)\end{array}$ & $\begin{array}{c}0.009 \\
0.0407\end{array}$ & 0.040 & 0.32 & 0.13 & 0.035 \\
\hline $\begin{array}{l}\text { Model 2, adjusted } \\
\text { P value }\end{array}$ & $\begin{array}{c}-0.03(-0.05,0.00) \\
\mathbf{0 . 0 3 8}^{\mathrm{b}}\end{array}$ & $\begin{array}{c}-0.04(-0.07,-0.02) \\
\mathbf{0 . 0 0 1}\end{array}$ & $\begin{array}{c}-0.02(-0.05,0.00) \\
\mathbf{0 . 0 0 1}\end{array}$ & $\begin{array}{c}-0.00(-0.02,0.02) \\
0.92\end{array}$ & $\begin{array}{c}-0.02(-0.04,0.01) \\
\mathbf{0 . 0 3 0}\end{array}$ & $\begin{array}{c}-0.06(-0.09,-0.02) \\
\mathbf{0 . 0 0 1}\end{array}$ \\
\hline \multicolumn{7}{|l|}{ Group-10, n=402 } \\
\hline $\begin{array}{l}\text { Model } 1 \text {, unadjusted } \\
\mathrm{P} \text { value }\end{array}$ & $\begin{array}{c}-0.04(-0.09,0.02) \\
0.16\end{array}$ & $\begin{array}{c}-0.07(-0.12,-0.02) \\
\mathbf{0 . 0 0 8}\end{array}$ & $\begin{array}{c}-0.06(-0.11,-0.02) \\
\mathbf{0 . 0 0 9}\end{array}$ & $\begin{array}{c}0.02(-0.04,0.07) \\
0.56\end{array}$ & $\begin{array}{c}-0.03(-0.08,0.02) \\
0.20\end{array}$ & $\begin{array}{c}-0.06(-0.11,-0.01) \\
\mathbf{0 . 0 1 1}\end{array}$ \\
\hline $\begin{array}{l}\text { Model } 2 \text {, adjusted } \\
\quad \mathrm{P} \text { value }\end{array}$ & $\begin{array}{c}-0.03(-0.07,0.01) \\
0.19\end{array}$ & $\begin{array}{c}-0.05(-0.10,-0.01) \\
\mathbf{0 . 0 1 6}\end{array}$ & $\begin{array}{c}-0.06(-0.11,-0.01) \\
\mathbf{0 . 0 1 8}\end{array}$ & $\begin{array}{c}0.01(-0.04,0.06) \\
0.68\end{array}$ & $\begin{array}{c}-0.02(-0.07,0.02) \\
0.33\end{array}$ & $\begin{array}{c}-0.06(-0.11,-0.01) \\
\mathbf{0 . 0 1 8}\end{array}$ \\
\hline \multicolumn{7}{|l|}{ Group-30, n=410 } \\
\hline $\begin{array}{l}\text { Model } 1 \text {, unadjusted } \\
\mathrm{P} \text { value }\end{array}$ & $\begin{array}{c}-0.03(-0.07,0.01) \\
0.12\end{array}$ & $\begin{array}{c}-0.05(-0.09,-0.01) \\
\mathbf{0 . 0 0 9}\end{array}$ & $\begin{array}{c}-0.04(-0.08,-0.01) \\
\mathbf{0 . 0 1 8}\end{array}$ & $\begin{array}{c}-0.03(-0.06,0.01) \\
0.15\end{array}$ & $\begin{array}{c}-0.04(-0.08,-0.00) \\
\mathbf{0 . 0 4 9}\end{array}$ & $\begin{array}{c}-0.04(-0.08,-0.01) \\
\mathbf{0 . 0 2 1}\end{array}$ \\
\hline Model 2, adjusted ${ }^{\mathrm{a}}$ & $-0.02(-0.06,0.01)$ & $-0.04(-0.07,0.00)$ & $-0.04(-0.06,-0.02)$ & $-0.01(-0.03,0.01)$ & $-0.04(-0.06,-0.02)$ & $-0.04(-0.07,-0.01)$ \\
\hline$P$ value & 0.13 & 0.034 & 0.027 & 0.56 & 0.062 & 0.032 \\
\hline
\end{tabular}

Values are beta coefficients $(95 \% \mathrm{Cl})$ per $10 \mathrm{nmol} / \mathrm{L}$ increase in $25(\mathrm{OH}) \mathrm{D}$ concentration based on linear regression.

SDS, standard deviation score, based on Finnish sex- and age-specific normative data for infant growth; 25(OH)D, blood 25-hydroxyvitamin D concentration;

MUAC, mid-upper-arm circumference; BMI, body mass index.

${ }^{a}$ Model 2 is adjusted for the corresponding birth size SDS (except for MUAC and BMI; the covariate was length-adjusted birth weight), maternal and paternal height z-scores and intervention group.

${ }^{b}$ Additional adjustment for maternal prepregnancy BMI, paternal BMI, parental smoking status, parental education level, family income level, and duration of breastfeeding attenuated the association to $\mathrm{P}=0.054$.

Missing values: 2 values missing from weight, length-adjusted weight and BMI; 14 values missing from head circumference; 17 values missing from MUAC. 

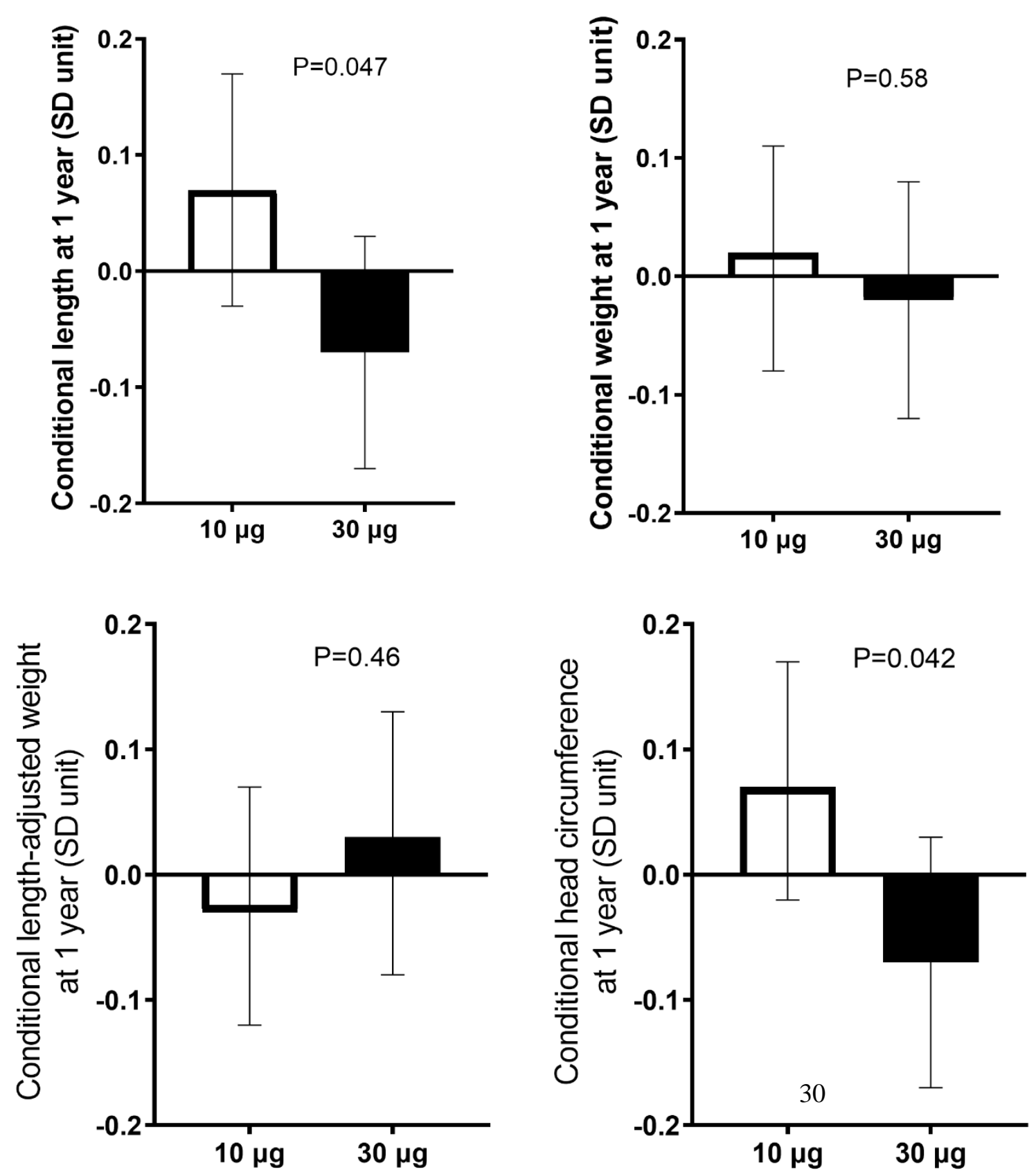

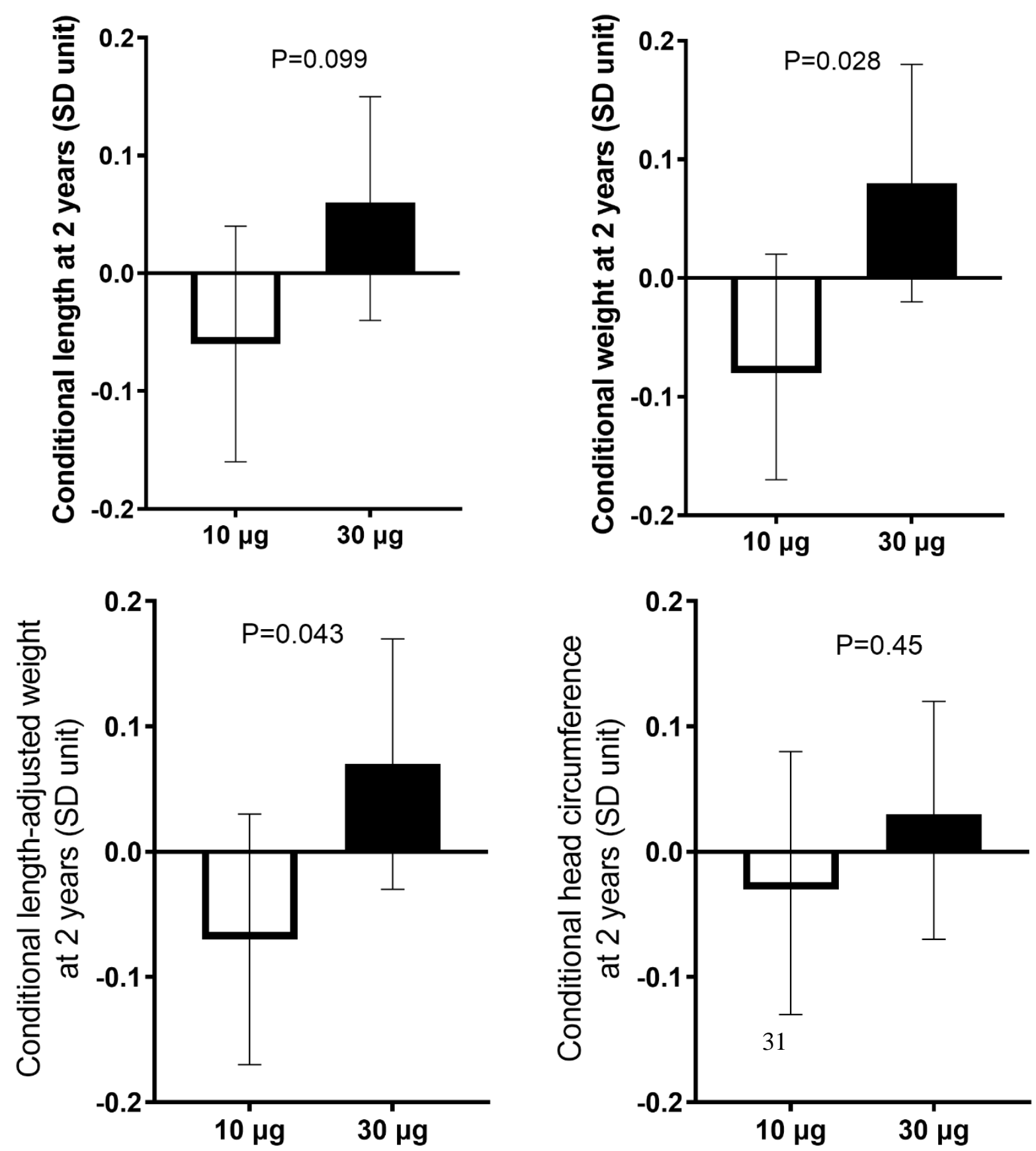
Pregnancy 25(OH)D and offspring growth measures at 2 years $(n=680)$

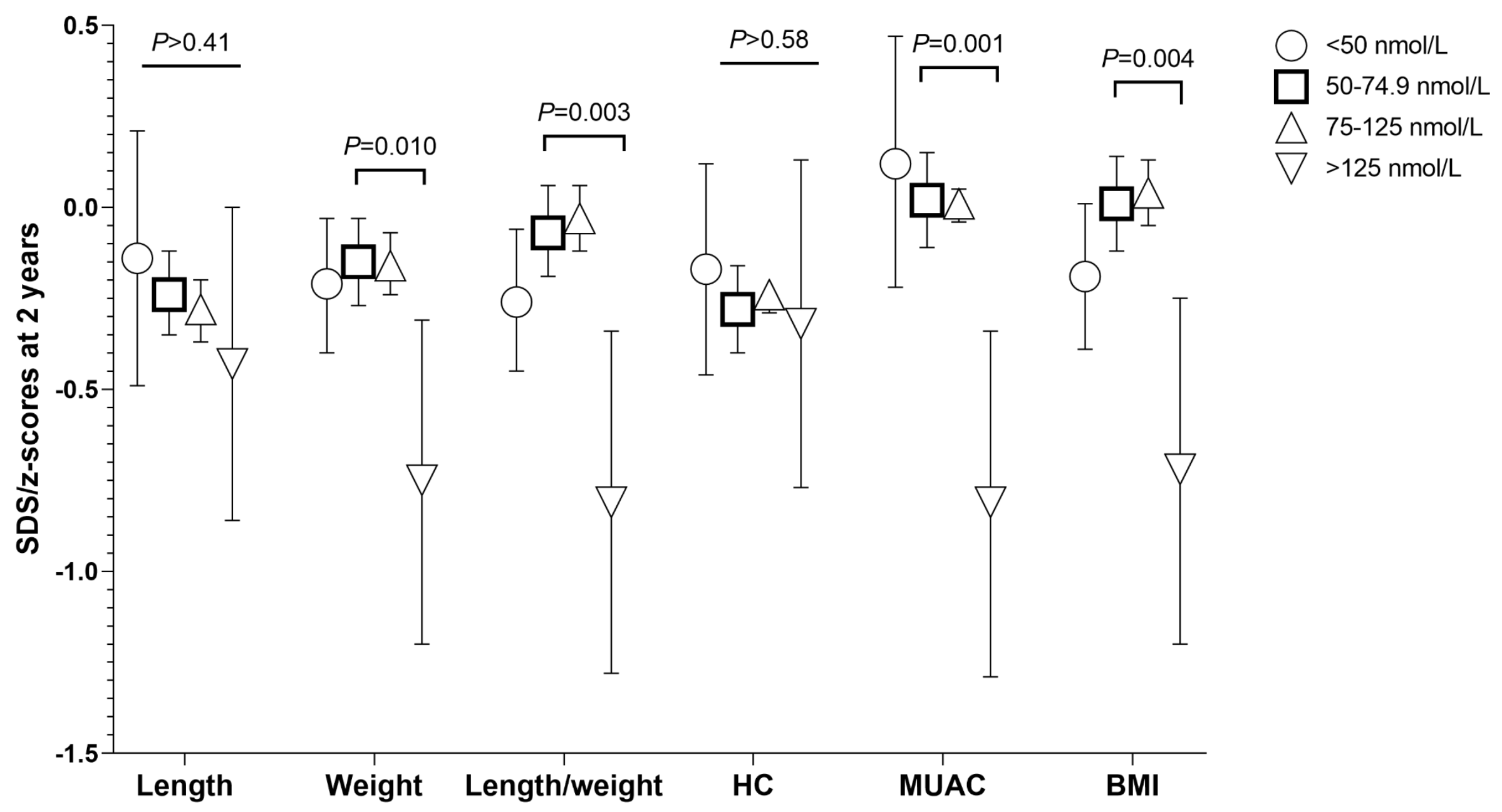


UCB 25(OH)D and offspring growth measures at 2 years $(n=794)$

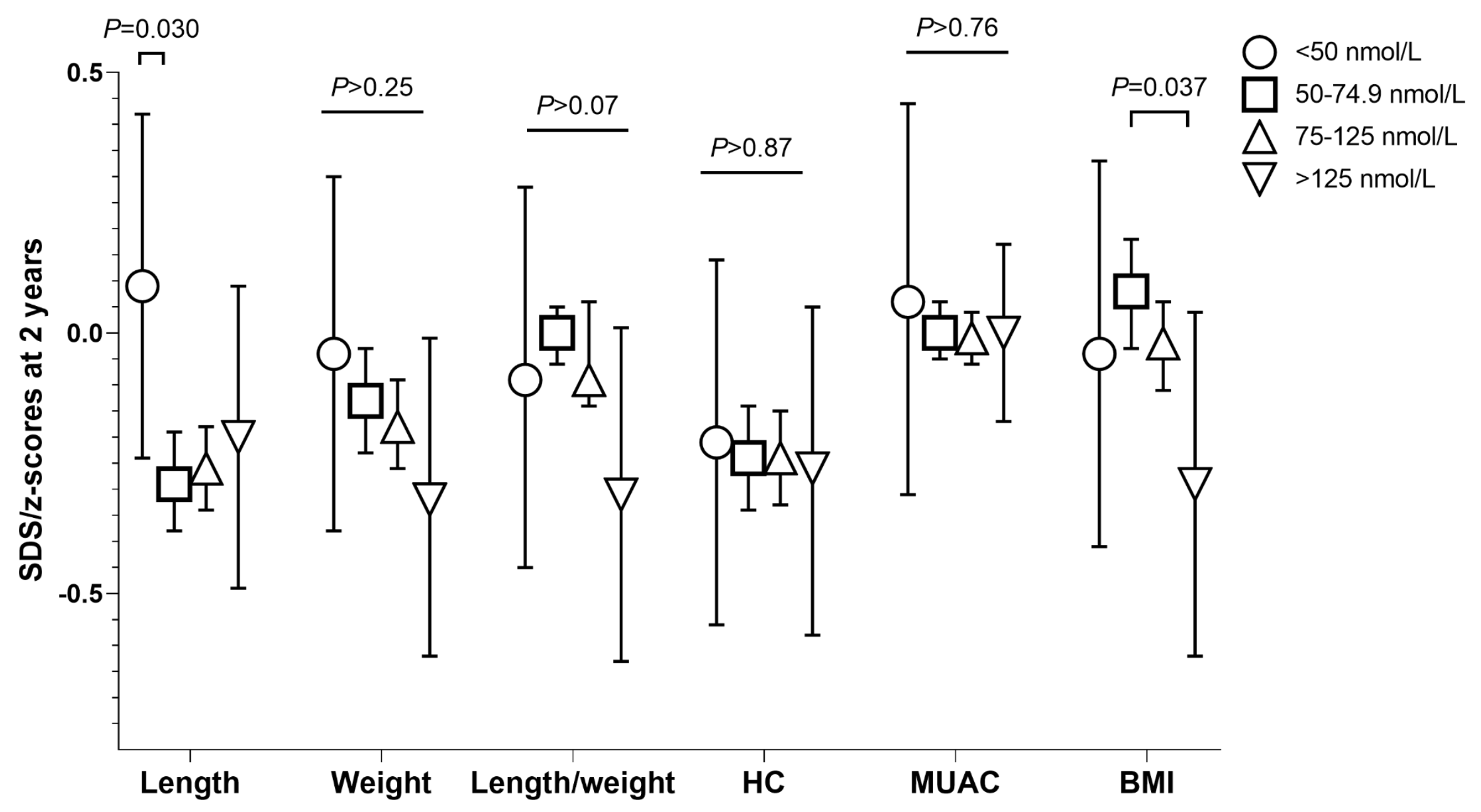


Toddler 25(OH)D and growth measures at 2 years $(n=812)$

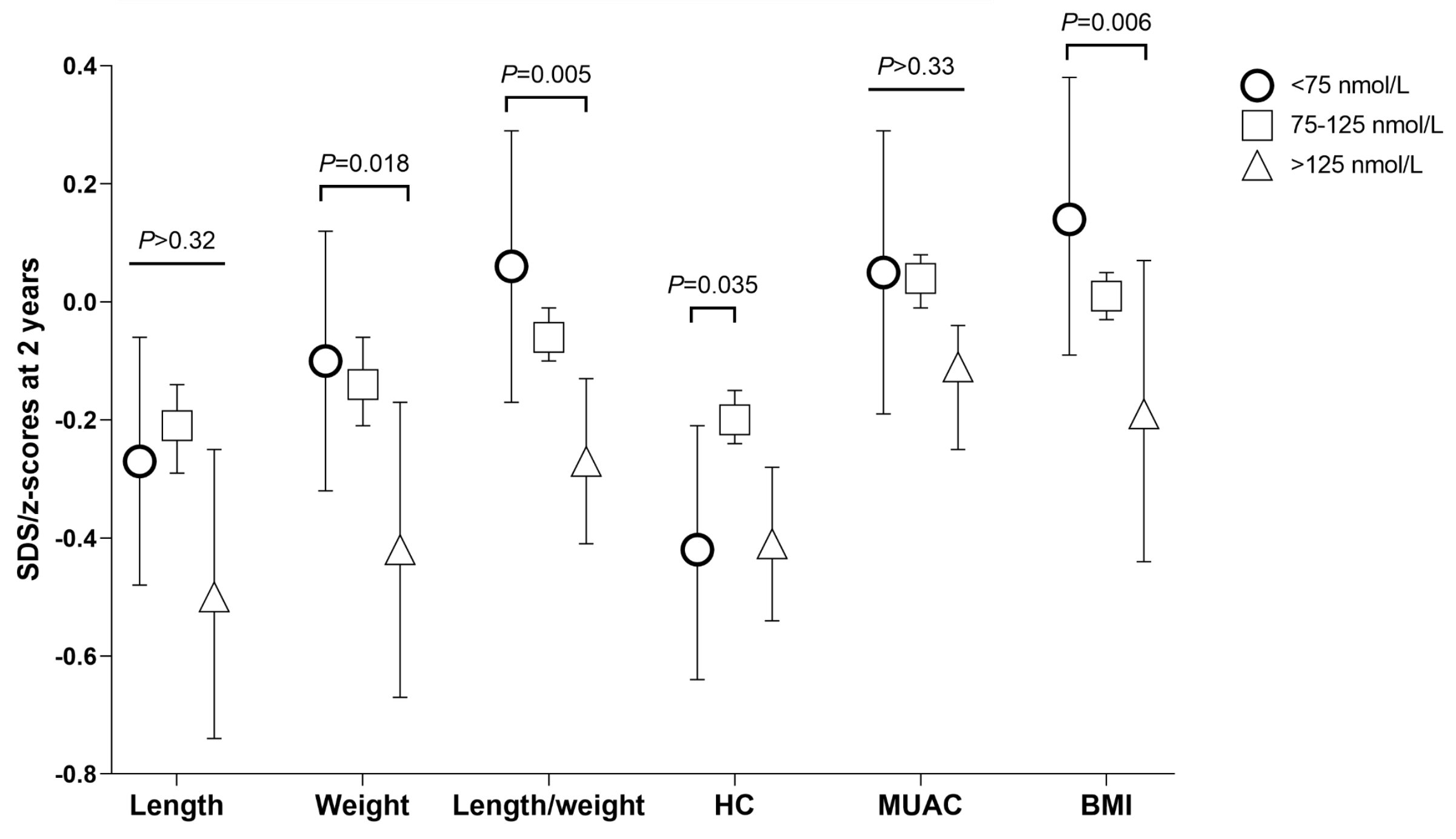


Toddler 25OHD at 2 years in quartiles $(n=812)$

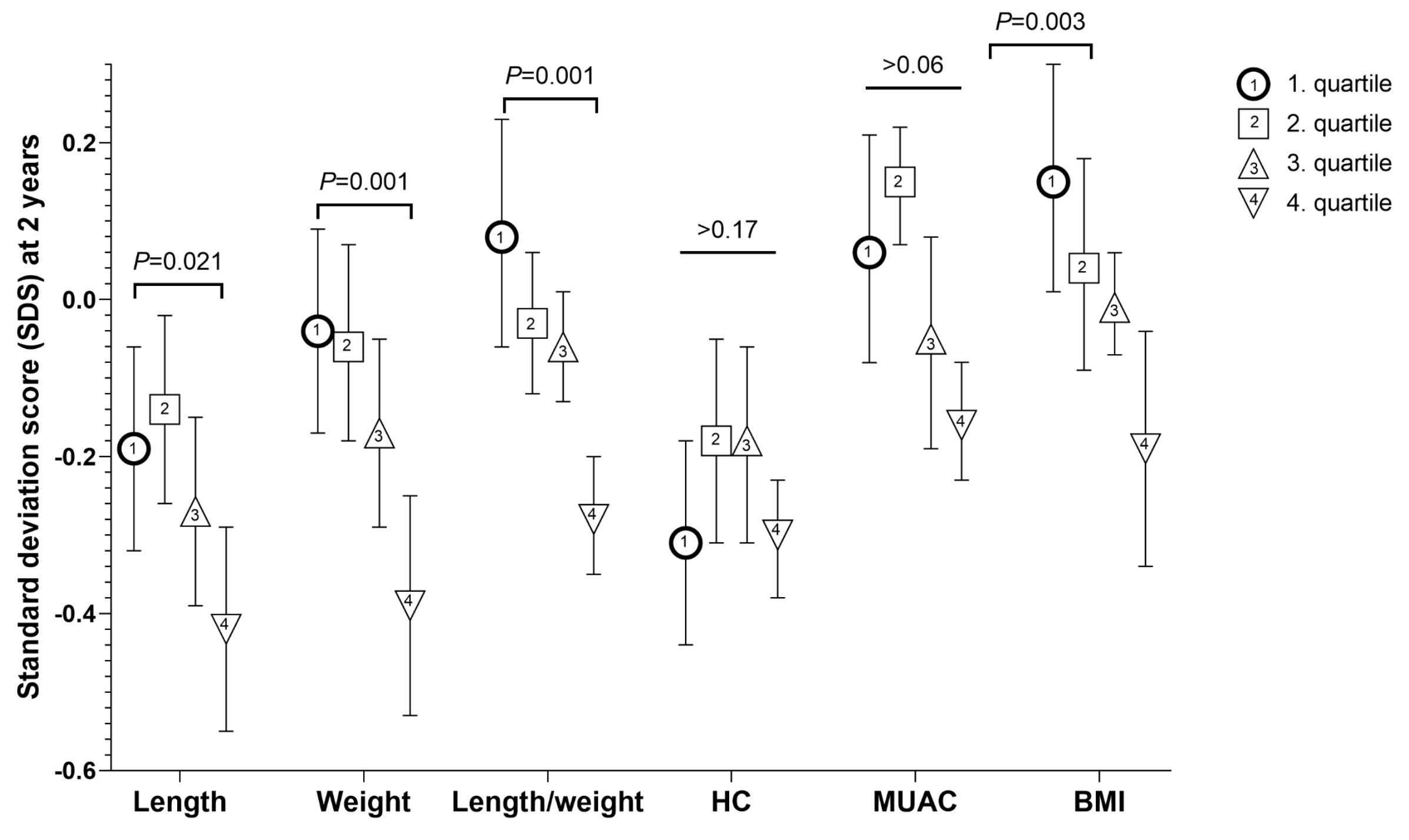

